IZA DP No. 5021

Do Bans on Affirmative Action Hurt Minority Students? Evidence from the Texas Top 10\% Plan

Kalena E. Cortes

June 2010 


\title{
Do Bans on Affirmative Action Hurt Minority Students? Evidence from the Texas Top 10\% Plan
}

\author{
Kalena E. Cortes \\ Syracuse University \\ and IZA \\ Discussion Paper No. 5021 \\ June 2010 \\ IZA \\ P.O. Box 7240 \\ 53072 Bonn \\ Germany \\ Phone: +49-228-3894-0 \\ Fax: +49-228-3894-180 \\ E-mail: iza@iza.org
}

Any opinions expressed here are those of the author(s) and not those of IZA. Research published in this series may include views on policy, but the institute itself takes no institutional policy positions.

The Institute for the Study of Labor (IZA) in Bonn is a local and virtual international research center and a place of communication between science, politics and business. IZA is an independent nonprofit organization supported by Deutsche Post Foundation. The center is associated with the University of Bonn and offers a stimulating research environment through its international network, workshops and conferences, data service, project support, research visits and doctoral program. IZA engages in (i) original and internationally competitive research in all fields of labor economics, (ii) development of policy concepts, and (iii) dissemination of research results and concepts to the interested public.

IZA Discussion Papers often represent preliminary work and are circulated to encourage discussion. Citation of such a paper should account for its provisional character. A revised version may be available directly from the author. 
IZA Discussion Paper No. 5021

June 2010

\section{ABSTRACT}

\section{Do Bans on Affirmative Action Hurt Minority Students? Evidence from the Texas Top 10\% Plan ${ }^{*}$}

In light of the recent bans on affirmative action in higher education, this paper provides new evidence on the effects of alternative admissions policies on the persistence and college completion of minority students. I find that the change from affirmative action to the Top $10 \%$ Plan in Texas decreased both retention and graduation rates of lower-ranked minority students. Results show that both fall-to-fall freshmen retention and six-year college graduation of second-decile minority students decreased, respectively, by 2.4 and 3.3 percentage points. The effect of the change in admissions policy was slightly larger for minority students in the third and lower deciles: fall-to-fall freshmen retention and six-year college graduation decreased, respectively, by 4.9 and 4.2 percentage points. Moreover, I find no evidence in support of the minority "mismatch" hypothesis. These results suggest that most of the increase in the graduation gap between minorities and non-minorities in Texas, a staggering 90 percent, was driven by the elimination of affirmative action in the 1990s.

JEL Classification: $\quad$ I21, I23, J15, J24

Keywords: affirmative action, Top 10\% Plan, college quality, freshmen retention, college graduation

Corresponding author:

Kalena E. Cortes

Syracuse University

350 Huntington Hall

Syracuse, NY 13244-2340

USA

E-mail: kcortes@syr.edu

\footnotetext{
* This paper was previously circulated under the title "College Quality and the Texas Top 10\% Plan: Implications for Minority Students." I would like to thank David E. Card, Charles Clotfelter, Alan B. Krueger, Caroline M. Hoxby, Cecilia E. Rouse, and Marta Tienda for all of their encouragement and most valued advice throughout this research. Also, I would like to thank Charles Udomsaph, Benjamin A. Campbell, Angela Fertig, Erica M. Field, Daniel Kian Mc Kiernan, Jesse Rothstein, Audrey B. Welber, seminar participants at U.C. Berkeley, Princeton University, Swarthmore College, Harvard Graduate School of Education, Columbia University Teachers College, and The Ohio State University for their comments, Texas Higher Education Opportunity Projects (THEOP) members, and the NBER Higher Education Working Group participants. Grants from the National Institute of Child Health and Human Development (NICHD); Ruth L. Kirschstein National Service Award Individual Fellowship (PHS Grant No. 1-F32-HD043588-01A1); Ford, Mellon, Hewlett, and Spencer Foundations; NSF (Grant No. SES-0350990); and W.E. Upjohn Institute for Employment Research (Grant No. 07-106-07) are gratefully acknowledged. Institutional support from the Office of Population Research, Princeton University (NICHD Grant No. R24-H0047879), Syracuse University, Harvard University, and the National Bureau of Economic Research are also gratefully acknowledged. Research results, conclusions, and all errors are naturally my own.
} 


\section{Introduction}

Few things are as persistent as the educational gap between minorities and their nonminority counterparts in the United States; this gap has only slightly narrowed over time (U.S. Department of Education 2005). Because of the significant market premiums attached to the possession of a college degree, minimizing the gap in educational attainment is of great concern to policymakers. Previous studies have found that the real market premium stems from attending a more selective college (Black and Smith 2004; Brewer, Eide, and Ehrenberg 1999; Brewer and Ehrenberg 1996; Bowen and Bok 1998). ${ }^{1}$ If college quality does indeed matter, then social policies such as affirmative action in college admissions can potentially help close this pervasive educational gap.

In recent years, however, the effectiveness of affirmative action policies in higher education has been widely debated. Critics of race-sensitive admissions policies maintain that such policies only hinder the intended beneficiaries (Thernstrom and Thernstrom 1997, 1999; Graglia 1993), and cite the lower postsecondary graduation rates of minority students at selective colleges as evidence of a "mismatch." The logic behind this argument is that the graduation rates for minority students would be higher if they enrolled in institutions whose academic prerequisites were a better "match" to their academic credentials, rather than overreaching and enrolling at institutions where they are overshadowed academically by their classmates. $^{2}$ On the other hand, proponents of affirmative action argue that minority students, despite their lower level of preparedness, nevertheless perform well and benefit

\footnotetext{
${ }^{1}$ For a detailed review of the earlier literature on the effects of college quality, see Brewer and Ehrenberg (1996).

${ }^{2}$ While the main outcomes of mismatch considered in this paper are lower retention and graduation rates, the term can also refer to lower grade point averages or easier academic majors.
} 
from attending selective institutions (Alon and Tienda 2005; Bowen and Bok 1998; Kane 1998a, 1998b; Dee 2004). ${ }^{3}$

As concern mounts over the changing legal status of affirmative action policies in college admissions, it is important to analyze the impact of alternative admissions policies on the postsecondary educational outcomes of minority students. In fact, certain states that banned the use of racial preferences in college admissions have now implemented high school rank-based policies_-dubbed "top x-percent" plans-in their place. Texas was among the first states to legislate such a policy, and passed its Top 10\% Plan following the landmark Hopwood v. University of Texas Law School ruling in 1996, which judicially banned the use of race in admissions decisions at all public postsecondary institutions. Under this ranked-based admissions policy, Texas high school students in the top 10 percent of their graduating senior class are automatically guaranteed admission to any four-year public university of their choice, including the selective University of Texas at Austin and Texas A\&M University at College Station. Students most affected by this change in admissions policy were minority students ranked in the second and lower deciles, whereas first decile students were sufficiently qualified to be admitted under both admissions regimes. ${ }^{4}$

Texas provides a setting in which we can evaluate an alternative admissions policy in higher education. Based on institutional administrative data obtained from several public universities in Texas, this paper contributes to the existing research on the use of alternative admissions policies in higher education and also the minority "mismatch" hypothesis. As the institutional data span both the affirmative action admissions and Top 10\% Plan

\footnotetext{
${ }^{3}$ Conversely, Sander (2004) calls into question the benefits for minority students from attending selective colleges and finds that race-sensitive admissions in law schools reduced the number of black law students who pass the bar exam and eventually become lawyers. However, Sanders (2004) has now been debunked (Ho 2005; Ayres and Brooks 2005; Rothstein and Yoon 2006).

${ }^{4}$ Prior to the Top $10 \%$ Plan, students who were ranked in the first decile, although not guaranteed, were nevertheless virtually assured of admission to UT-Austin (Tienda et al. 2003; Walker and Lavergne 2001).
} 
regimes, I am able to analyze the impact of the change from race-sensitive to ranked-based admissions policies on college persistence and completion rates of lower-decile minority students. More specifically, in assessing the impact of the Texas Top 10\% Plan, I use a difference-in-differences procedure to analyze the effect of the change in admissions policies on fall-to-fall freshmen retention and six-year college graduation for this group.

The results show that both freshmen retention and college graduation rates of lowerdecile minority students declined after the change in admissions policies from affirmative action admissions to the Top 10\% Plan. The proposed mechanism by which lower-ranked minority students are being impacted is through their lower admission rates to (and ultimately lower attendance at) selective public colleges during the Top 10\% Plan. Thus, these students cascaded down and ended up attending less selective institutions under the Top $10 \%$ Plan. I find that the change in admissions policies lowered the freshmen retention rates of second-decile minority students by 2.4 percentage points and third- (and below) decile minority students by 4.9 percentage points. I also find that under the Top $10 \%$ Plan the graduation rate of second-decile minority students declined by 3.3 percentage points, and similarly, the graduation rate of third- (and below) decile minority students declined by 4.2 percentage points. Moreover, I find no evidence to support the minority "mismatch" hypothesis, which would have predicted retention and graduation rates of lower-ranked minority students to have improved under the Top 10\% Plan admissions policy.

The change in admissions policies from affirmative action to the Top 10\% Plan negatively impacted lower decile minority students. The analysis suggests that the elimination of affirmative action in the 1990s only served to increase the pervasive racial gap in postsecondary educational attainment in Texas. My results suggest that most of this increase in the graduation gap between minorities and non-minorities in Texas, a staggering 
90 percent, was driven by the change in admissions policy from affirmative action to the Top 10\% Plan.

The paper is organized as follows: Section 2 provides some background on the Texas Top 10\% Plan and presents a literature review; Section 3 discusses the empirical strategy used in the paper; Section 4 describes the data used in the analysis and sample characteristics; Section 5 reports and discusses the main results; Section 6 presents a robustness analysis; and Section 7 concludes.

\section{Top $10 \%$ Plan and Relevant Literature}

Passed on May 20th 1997 during the governorship of George W. Bush, the H.B.588 Law-more commonly known as the Top 10\% Plan-was implemented in response to the landmark ruling of the $5^{\text {th }}$ Circuit Court's decision in Hopwood v. University of Texas Law School, which judicially banned the use of race in admissions decisions in all public postsecondary institutions in Texas. ${ }^{5}$ This statewide change in college admissions policies was felt immediately, especially at the two most selective public institutions, the University of Texas at Austin and Texas A\&M University at College Station, where the number of minority enrollees plummeted (Tienda et al. 2003; Bucks 2004; Lavergne and Faulkner 2001). Unlike the top x-percent plans implemented by other states (e.g., California, Washington, and Florida), the Top 10\% Plan guaranteed automatic admission to any public university of choice to all seniors who graduate in the first decile of their graduating high school class. ${ }^{6,7}$ Proponents of the plan believed the new admissions policy would restore campus diversity

${ }^{5}$ See Hopwood v. University of Texas Law School 78 F.3d 932, 944 (5th Cir. 1996).

6 The University of California system guarantees a slot at a UC campus for the top 4 percent of students from each high school in the state, and the allocation of students to specific campuses is a system-wide decision. Similarly, the Talented 20 Plan in Florida guarantees the top 20 percent of public high school graduates admission to a college, but students are assigned to an institution. 
because of the high degree of segregation among high schools in Texas; the intent was that the number of minority students rank-eligible under the Top 10\% Plan would be sufficient to restore campus diversity throughout the state (Yardley 2002; Hockstader 2002).

To date, most of the research conducted on the ban of affirmative action admissions in favor of the Top 10\% Plan in Texas has thoroughly analyzed its effect on application, admission, and enrollment probabilities of minority and non-minority students to colleges (Dickson 2006; Card and Krueger 2005; Tienda et al. 2003; Bucks 2004; Lavergne and Faulkner 2001; Niu, Tienda, and Cortes 2006); have looked at the potential strategic behavior of high school switchers induced by the Top 10\% Plan (Cullen, Reback, and Long 2009); or have measured the externalities generated by households moving to areas with lowperforming high schools (Cortes and Friedson 2010). However, none have analyzed the effect of this policy ban on the college outcomes of lower-ranked minority students- the group of students most affected by the change from race-based to rank-based admissions.

Tienda et al. (2003) was among the first studies to document the decline in black and Hispanic students at the two most selective public institutions in Texas, UT-Austin and Texas A\&M, where undergraduate black and Hispanic enrollments dropped by roughly one and over two percentage points, respectively. The paper also finds that implementation of the Top 10\% Plan alone after the Hopwood ruling was unable to restore campus diversity at these Texas flagship institutions to pre-Hopwood levels of black and Hispanic student enrollment (see also Horn and Flores 2003). Moreover, the study by Dickson (2006) uses a panel of Texas high schools and finds that the percentage of black and Hispanic students who took college entrance exams fell when affirmative action admissions was banned in the state, while the percentage of white students who took college entrance exams did not

${ }^{7}$ Although private universities are duty-bound by the Hopwood ruling, they are not subject to the automatic 
change. Lastly, Bucks (2004) analyzes college choice among Texas high school students and finds a lower probability among minority students and a higher probability among nonminority students of enrolling in selective in-state public institutions after the implementation of the Top $10 \%$ Plan.

Despite the growing number of states that have now implemented a top x-percent admissions policy, there is scant evidence on the effects of this policy on college outcomes of non-top x-percent students. Arguably, lower-ranked minorities were the group of students most affected by the elimination of affirmative action policies in college admissions. The few studies that do examine these top x-percent policies analyze institutional responses to these percent policies (Faulkner 2000) or focus on the top x-percent students at those institutions (Leicht and Sullivan 2000). For instance, UT-Austin in 2000 had to increase the size of the entering freshman cohort in order to facilitate the rise in applicants who graduated in the first decile of their class (Faulkner 2000). A study by Leicht and Sullivan (2000), using administrative data from UT-Austin, finds that overall freshmen attrition declined from 12.9 percent in 1995 to 10.7 percent in 1998, and of the 1998 entering freshmen cohort, 88 percent of the top $10 \%$ students had returned for the 2000 spring semester. Most recently, in 2009, Texas placed some limits on student institutional choice, and UT-Austin is now allowed to restrict the number of top $10 \%$ students to 75 percent of the entering freshman class. Moreover, the void in analysis of non-top x-percent students partly reflects data availability constraints, as most national postsecondary educational databases have limited information on student high school transcripts and do not contain information on the exact high school class rank of each student. The institutional data used

admissions guarantee (Tienda et al. 2003). 
in this study were collected specifically to address these questions that existing educational databases are unable to address.

Most importantly, the analysis of lower-ranked minority students under this alternative admissions policy speaks directly to the claims of the "mismatch" hypothesis, that is, the argument that minority students would have had better college outcomes had they attended an institution that better matched their academic preparedness. Studies examining academic performance among minority students attending selective colleges have found a positive association between overall academic performance and college selectivity (Alon and Tienda 2005; Bowen and Bok 1998; Kane 1998a, 1998b; Kane and Dickens 1996, Fisher and Massey 2007; an exception is Loury and Garman 1993, 1995). ${ }^{8}$ Bowen and Bok (1998), using data from College and Beyond, was among the first studies to tackle the mismatch hypothesis, showing that graduation rates increased for both black and white students at all SAT levels as the quality of the institution they attended increased. ${ }^{9}$ Interestingly, Fischer and Massey (2007) finds that for black and Hispanic students attending elite private institutions, having an SAT score below the institutional average was associated with a slight increase in freshmen grades for these minority groups. All of these studies find that minority students at selective colleges have higher grades and graduation rates, a result that clearly runs counter to the mismatch hypothesis.

It is also worth pointing out that most of the research conducted on affirmative action policies in higher education has been limited to the analysis of private elite colleges

\footnotetext{
8 Studies by Loury and Garman $(1993,1995)$ report an exception to this general pattern of findings. The authors use data from the National Longitudinal Study of the High School Class of 1972 (NLSY-72) and find that black students obtained lower grades and earned lower future earnings if they are "mismatched" with their institution.

${ }^{9}$ However, Bowen and Bok (1998) coined it the "fit" hypothesis.
} 
with very little coverage of public institutions. This paper examines these understudied public institutions.

\section{Empirical Strategy}

A difference-in-differences approach is used to analyze the effect of the change in admissions policies on fall-to-fall freshmen retention and six-year college graduation for minority students ranked in the second and lower deciles. The assumption behind this empirical strategy is that the Top $10 \%$ Plan did not affect students ranked in the first decile since these students were qualified under both admissions policies, but did affect students ranked in the second and lower deciles. These students were largely left to enroll in less selective colleges under this alternative admissions policy. In the difference-in-differences framework, minority students ranked in top 10 percent serve as the control group, and the two treatment groups are minority students ranked in the second and lower deciles.

The following model specification is estimated by ordinary least squares (OLS) to analyze the effect of the Top 10\% Plan on retention and graduation rates of lower-ranked minority students,

$$
\begin{aligned}
& Y_{i t}=\alpha+\sum_{k=1990, k \neq 1997}^{1999} \beta_{k} \cdot I\left(\text { Cohort }_{t}=k\right)+\gamma_{1} \cdot \text { Decile }_{i t}^{2 n d}+\gamma_{2} \cdot \text { Decile }_{i t}^{3 r d} \text { plus }+ \\
& \delta_{1} \cdot \text { Post }_{i} \cdot \text { Decile }_{i t}^{2 n d}+\delta_{2} \cdot \text { Post }_{i} \cdot \text { Decile }_{i t}^{\text {3rd }} \text { plus }_{\text {flt }}+S_{i t} \cdot \phi+H S_{i t} \cdot \psi+\varphi+\varepsilon_{i t}
\end{aligned}
$$

where $Y_{i t}$ is a binary variable that indicates fall-to-fall freshmen retention or college graduation within six years for student $i$ in cohort (college entry) t. $I(\cdot)$ is an indicator function associated with cohort $t$. Post ${ }_{i}$ is a binary variable that indicates if student $i$ is observed under the Top 10\% Plan (i.e., equal to 0 if student $i$ is observed in cohorts 1990 
through 1996 or equal to 1 if student $i$ is observed in cohorts 1998 through 1999). Decile ${ }_{i t}^{2 n d}$

and Decile ${ }_{i t}^{3 r d}$ - plus are indicator variables for students ranked in the second decile (i.e., 11-20

percentile class rank) and in the third and below deciles (i.e., 21-100 percentile class rank), respectively. Post ${ }_{i}$ multiplied by Decile ${ }_{i t}^{2 n d}$ and Decile ${ }_{i t}^{3 r d}-$ plus $^{\text {, }}$, respectively, are interactions of these variables. $S_{i t}$ and $H S_{i t}$ are vectors of student-level and high school-level characteristics, respectively. More specifically, $S_{i t}$ includes Scholastic Aptitude Test (SAT) scores and indicator variables for gender and race or ethnicity. ${ }^{10} H S_{i t}$ includes mean high school SAT score, feeder high school status, school location indicators (i.e., suburban, town, rural, and urban, which is the omitted category), percentage of free lunch eligible students, and percentage of minority students. ${ }^{11,12} \varphi$ is a vector of high school fixed effects. Lastly, $\varepsilon_{i t}$ is a normally distributed random error term.

The coefficients of the above difference-in-differences framework have the following interpretation: $\beta_{k}$ 's capture the yearly cohort differences in the average outcomes over time that are common to both the treatment groups (i.e., students ranked in the second and lower deciles) and the control group (i.e., top 10\% students); $\gamma_{1}$ and $\gamma_{2}$ capture the

\footnotetext{
10 The race or ethnicity omitted category will depend on the specific subsample being analyzed. When the minority subsample is being analyzed, the three indicator variables are Hispanic (omitted), black, and Native American students. When the non-minority subsample is being analyzed, the two indicator variables are nonHispanic white (omitted) and Asian students.

11 The feeder high school indicator variable identifies schools that have extremely strong college-going traditions. Because these feeder high schools supply a large proportion of their high school graduates to the selective colleges, I include a control for this type of high school in the analysis. For instance, the top 20 feeder high schools accounted for 12 percent of students that were admitted to Texas A\&M in 2000, and a little over 22 percent of these students contributed to the entering freshmen class. The corresponding figures for UT-Austin are even higher-23 and 35 percent, respectively (Tienda et al. 2003).

12 The analysis controls for time variant high school characteristics to account for possible changes in the high school type of students after the adoption of the Top 10\% Plan. Moreover, the admission years under the Top 10\% Plan analyzed in this paper are 1998 and 1999; these early years do not capture other effects induced by this new admissions policy, such as students who intentionally switched high schools in order to be ranked in the first decile, as shown by Cullen, Reback, and Long (2009).
} 
average permanent differences between the two treatment groups and the control group; and lastly, of particular interest are the coefficients $\delta_{1}$ and $\delta_{2}$, which are the difference-indifferences estimators that capture the effect of the Top 10\% Plan. More specifically, these parameters measure the differences in outcomes (i.e., retention or graduation) before and after the Top 10\% Plan for the two treatment groups, compared to the corresponding difference for the control group.

Equation (1) is estimated separately for both minority and non-minority samples. Although the focus of this paper is to analyze the effect of the change in admissions policies from affirmative action to the Top $10 \%$ Plan on minorities, a parallel analysis on the nonminority student sample is interesting in its own right since elimination of racial preferences and implementation of the Top 10\% Plan is expected to have also affected non-minority students. Affirmative action presumably "crowded-out" some non-minorities from attending selective institutions in Texas - that is, non-minorities who would have gained access to selective institutions on the basis of merit in the Top $10 \%$ new admissions era.

\section{Data and Sample Characteristics}

\subsection{Data Sources}

Data for the analysis come from the administrative data component of the Texas Higher Education Opportunity Project (THEOP), comprising nine institutions in Texas (two private and seven public) that differ in admissions selectivity and overall institutional ranking. The present study is based on data from six of the nine institutions; data coverage for some universities do not span both admissions policies. 
Figure 1 presents maps that identify the location of the nine THEOP universities and displays the percentage of minorities (total, blacks, and Hispanics) in the population by county in 2000. ${ }^{13}$ The six universities used in the analysis (whose locations are marked by stars on the maps) are the University of Texas at Austin (UT-Austin), Texas A\&M University at College Station (Texas A\&M), Texas Tech University (Texas Tech), Texas A\&M University at Kingsville (TAMU-Kingsville), the University of Texas at San Antonio (UTSan Antonio), and the University of Texas at Pan American (UT-Pan American). Of these six institutions, UT-Austin and Texas A\&M are considered to be the most selective public state colleges in Texas (Barron's College Division 2002), and they have been the target of most of the debate on affirmative action admissions policies in Texas. As shown in Figure 1, Hispanics reside predominately in South Texas, whereas blacks reside predominantly in the Eastern part of the state. Figure 1 also illustrates the high degree of segregation that still exists in Texas and supports the rationale of Top 10\% Plan proponents who argue that it would restore campus diversity.

The THEOP institutional data provide the total number of applicants, admittances, and of those, enrollments for all universities across various admission years. For students who matriculated, full academic records are available for each semester of enrollment until graduation. These data contain the most important set of student characteristics used in the admissions process: SAT and ACT scores, exact high school class rank, gender, race and ethnicity, and other high school information. Since high school information of applicants is available in the data for all universities, I also use data from the National Center for Education

\footnotetext{
${ }_{13}$ All maps in this paper are generated using the program ArcView. The default classification method in ArcView called natural breaks is used to display the data. The natural breaks method identifies breakpoints between classes using a statistical formula (Jenk's optimization). Jenk's method (1967) minimizes the sum of the variance within each of the classes. Natural breaks finds groupings and patterns inherent in the data. Data used in these maps are from the 2000 U.S. Census.
} 
Statistics (NCES) and merge in high school characteristics by high school identification number and year of application; all high school variables used in the analysis are time variant. ${ }^{14}$

\subsection{Descriptive Statistics and Sample Characteristics}

Before turning to the descriptive statistics of the main analytic sample used in the paper, it is instructive to look at the admission rates of UT-Austin and Texas A\&M. If the proposed mechanism by which lower-ranked minority students are being impacted by the change in admissions policies is through their lower admission rates to (and ultimately lower attendance at) selective public colleges during the Top 10\% Plan, we should clearly be able to observe a sharp decline in the admission rates for lower-ranked minority students at these two most selective public institutions.

Hence, Table 1 reports the overall admission rates at UT-Austin and Texas A\&M by the two admissions policies: affirmative action (years 1990 through 1996) and the Top 10\% Plan (years 1998 and 1999). As seen in Table 1, the admission rates at these two colleges vary by admissions policies and minority group status. Throughout this paper, "minority" refers to black, Hispanic, and Native American students, whereas "non-minority" refers to Asian and non-Hispanic white students. Minority students experienced their highest admission rates during the affirmative action period ( 79 percent versus 71 percent). Nonminority students, on the other hand, experienced their highest admission rates during the Top 10\% Plan (80 percent versus 75 percent).

Most importantly, the change in admissions policies also affected the admission rates of students ranked in the lower deciles differently across minority group status. As shown in

14 The mean high school SAT variable, however, is obtained from the College Board and is based on all Texas 13 
the bottom two panels of Table 1, both minority and non-minority first decile students experienced close to a 100 percent admissions rate to these selective public colleges under both admissions regimes. ${ }^{15}$ For minority students ranked in the second and third (and below) deciles, admission rates at these selective colleges declined sharply when the admissions policy changed to the Top 10\% Plan. Specifically, the admission rates of minority students ranked in the second and third (and below) deciles at these selective colleges declined, respectively, by 10 and 14 percentage points (column (3) of panel B). Conversely, the admission rates of their non-minority counterparts at these selective colleges increased by 8 and 10 percentage points (column (3) of panel C).

I now turn to the descriptive statistics of the main analytic sample. Table 2 presents descriptive statistics of the control variables used in the analysis displayed in several dimensions. Panel A reports the summary statistics for the full sample of enrollees (column (1)); panel B reports the summary statistics for enrollees during the affirmative action years (column (2)) and enrollees by college selectivity (columns (3) and (4)); and lastly, panel C reports the summary statistics for enrollees during the Top 10\% Plan (column (5)) and enrollees by college selectivity (columns (6) and (7)).

The analytic sample consists of 120,452 students $(85,752$ students in the affirmative action period and 34,700 students in the Top 10\% Plan period) for the cohorts entering in 1990 through 1996 and cohorts entering in 1998 through $1999 .{ }^{16}$ In the sample, there are 30,868 minority and 89,584 non-minority students. As seen in panel A of Table 2, the average SAT score for the full analytic sample is 1,108 points and average class rank is 20

students who took the SAT in 1996. I thank Jesse Rothstein for making the data available for this paper.

15 Although the admission rate for first decile students is expected to be exactly at 100 percent during the Top $10 \%$ Plan regime, university officials attribute rejections to errors in student applications.

16 The 1997 student cohort is not included in the analysis since this cohort of students was admitted under an admissions policy in which neither affirmative action nor the Top 10\% Plan were in place. 
percentile points. The sample consist of 3.8 percent black, 21.5 percent Hispanic, 0.4 percent Native American, 7.3 percent Asian, and 67.1 percent non-Hispanic white students, and roughly half the sample is female.

Although the subsample characteristics of enrollees during the affirmative action years compared to those during the Top 10\% Plan years (column (2) versus column (5)) seem to have remained basically unchanged across these two distinct admissions policies, this is not the case if we further divide these two admission subsamples by students who enrolled at selective versus those who enrolled at less selective colleges (columns (3) and (4) of panel B versus columns (6) and (7) of panel C). ${ }^{17}$ Overall, there are observable differences in both student attributes and high school level characteristics for students who attended selective colleges compared to those who attended less selective colleges across both admissions policies. For instance, under both policies, students who enrolled in selective colleges have higher SAT scores and class rank. Also, students who enrolled in less selective colleges were more likely to have graduated from high schools whose students were eligible for the federally subsidized lunch program, a standard indicator of the average socioeconomic status of a high school. Lastly, students who enrolled in less selective colleges were more likely to have graduated from high schools that have a larger percentage of minority students.

However, the most important point illuminated by the division of affirmative action and the Top 10\% Plan samples by college selectivity is the difference in racial composition of enrollees at selective versus less selective colleges: there are far fewer minority students

\footnotetext{
${ }^{17}$ The classification of the six universities into selective and less selective groups is based on an independent postsecondary school ranking widely referenced in the college quality literature, Barron's Profiles of American Colleges 25th Edition (2002). The selective colleges consist of the two flagship institutions, UT-Austin and Texas A\&M, and the less selective colleges consist of the remaining four institutions: Texas Tech, TAMU-Kingsville, UT-San Antonio, and UT-Pan American.
} 
and many more non-minority students attending selective colleges under the Top 10\% Plan compared to the period when affirmative action admissions was in place (column (3) versus column (6)). Conversely, there are far more minority students and fewer non-minority students attending less selective colleges under the Top 10\% Plan compared to the affirmative action admission years (column (4) versus column (7)). These simple descriptive statistics indicate that minority students cascaded downward to less selective public institutions under the Top 10\% Plan. Moreover, this enrollment pattern falls in line with the observed declined in acceptance rates of lower decile minority students at selective colleges (shown in Table 1).

Lastly, Tables $3 \mathrm{~A}$ and $3 \mathrm{~B}$ present the unadjusted difference-in-differences estimates of the main outcome variables of interest: fall-to-fall freshmen retention and college completion within six years of enrollment. These unadjusted differences are shown separately by minority group status in Tables $3 \mathrm{~A}$ and $3 \mathrm{~B}$, respectively. There was a decline in both the retention and college graduation rates of minority students ranked in the second and third (and below) deciles under the Top 10\% Plan. As shown in panel A of Table 3A, freshmen retention rate of minority students ranked in the second and third (and below) deciles declined by 2.6 and 6.7 percentage points, respectively, under this alternative college admissions policy. Also, college completion within six years of enrollment of lower ranked minority students declined: the graduation rates of second- and third- (and below) decile minority students declined by 3.4 and 6.9 percentage points, respectively. In contrast, with the exception of the retention rate of students ranked in the third and below deciles, the difference-in-differences estimates (shown in Table 3B) for non-minority students show no effect of the Top 10\% Policy on the same deciles. 


\section{Results and Discussion}

The results from the difference-in-differences analysis are summarized in Table 4A for the minority sample. This table only reports the estimated coefficients on the post indicator variable interacted with the two treatment indicator variables (i.e., second and lower deciles), the two treatment indicator variables, and the constant. All regressions include cohort dummies (coefficients not reported). In Table 4A, model 1 presents the unadjusted baseline effects, model 2 controls for student characteristics, model 3 further controls for high school demographics, and model 4 adds in high school fixed effects. This table is further divided into two panels: panel A reports the regression results for the fall-to-fall freshmen retention outcome and panel B reports the regression results for the college completion outcome.

As panel A shows, there is a negative and statistically significant difference-indifferences estimates for all model specifications. Although the magnitude of these point estimates do vary slightly, the direction of these estimates are not sensitive to the addition of student and high school controls or to the addition of high school fixed effects. ${ }^{18}$ The results shown mirror the unadjusted difference-in-differences estimates previously reported in Table 3A. The preferred model specification for both outcomes of interest is model 3 as this specification includes the full set of covariates, which improves the efficiency of the difference-in-differences estimator. Controlling for student attributes and high school characteristics, I find that the change in admissions policies lowered the freshmen retention rates of second- and third- (and below) decile minority students, respectively, by 2.4 and 4.9 percentage points. Likewise, as shown in model 3 of panel B, I find that the change in admissions policies lowered the graduation rates of second- and third- (and below) decile

${ }^{18}$ Results are robust when the analytic sample is restricted to minority students in the top four to six deciles. 
minority students, respectively, by 3.3 and 4.2 percentage points. These results are also robust to the inclusion of high school fixed effects.

Since the minority mismatch hypothesis would have predicted an improvement in the retention and graduation rates of these lower-ranked minority students under the Top $10 \%$ Plan, the results of my analysis clearly run counter to this prediction. As shown in Table 1, there was a sizable decline in the admission rates of lower-decile minority students at selective colleges after the change in admissions policies. Moreover, these lower admission rates at selective colleges translate to a reduction in the number of minority students attending selective colleges and an increase in minority attendance at less selective colleges under the Top 10\% Plan compared to the affirmative action admissions years (shown in Table 2). According to the minority mismatch hypothesis, these students are now being better "matched" to an institution under this alternative admissions policy, whereas during the period of affirmative action admissions these students were "under-matched" academically to selective public institutions. If the mismatch hypothesis was valid, we should observe both an increase in retention and graduation rather than a decrease in both. The results from the analysis support previous studies that have used other methodological approaches to study the mismatch claim (Bowen and Bok 1998; Alon and Tienda 2005; Kane 1998a, 1998b; Fisher and Massey 2007).

I also conduct the same analysis on the non-minority student sample. Non-minority students were also impacted by the elimination of affirmative action policies (or the adoption of the Top 10\% Plan) in Texas. For the non-minority sample we should observe a positive effect of the Top 10\% Plan on freshmen retention and college completion of lower-ranked non-minority students. Recall from Table 1 that the admission rates of lower-ranked non- 
minority students at selective colleges increased by 8 and 10 percentage points, respectively, for students ranked in the second and third (and below) deciles.

The results of this analysis are reported in Table 4B, which has the exact layout as Table 4A. These results once again highlight the fact that the difference-in-differences point estimates are statistically insignificant for the college completion outcome (shown in panel B). Likewise, the difference-in-differences point estimates are statistically insignificant for the freshmen retention outcome for the second-decile non-minority students. However, there is a positive and statistically significant effect of the Top 10\% Plan on retention of third (and below) decile non-minority students: fall-to-fall freshmen retention increased by 2.4 percentage points.

Interestingly, these results seem to indicate that the elimination of affirmative action practices did not help non-minorities as much as it harmed the retention and graduation of minority students. While the admission rates of minority students in the second and lower deciles to UT-Austin and Texas A\&M declined substantially under the Top 10\% Plan, those of non-minorities in the second and lower deciles rose significantly (shown in Table 1). Moreover, the racial composition of enrollment at selective institutions also shifted toward non-minorities in the post-affirmative action period (shown in Table 2). However, these gains did not translate into higher college retention or graduation for non-minority students under the post-affirmative action era.

The change in admissions policies from affirmative action to the Top 10\% Plan negatively impacted lower decile minority students. The analysis suggests that the elimination of affirmative action in the 1990s actually increased the pervasive racial gap in postsecondary educational attainment in Texas. Under affirmative action over the period 1990 to 1996, 42 percent of minorities and 67 percent of non-minorities enrolled in public 
universities in Texas graduated within 6 years; under the Top 10\% Plan over the period 1998 to 1999, the graduation rates were 39 and 69 percent for minorities and non-minorities, respectively. My results suggest that most of this increase in the graduation gap between minorities and non-minorities in Texas, a staggering 90 percent, was driven by the change in admissions policy from affirmative action to the Top $10 \%$ Plan. ${ }^{19}$

\section{Robustness Analysis}

In order for the difference-in-differences analysis to identify the causal effect of the impact of the Top 10\% Plan, the difference-in-differences framework relies on the critical assumption that, in the absence of policy change, the average change in retention or graduation outcomes would have been the same for the two treatment groups and the control group. This critical assumption is formally called the parallel trends (or "common trends") assumption. It must be the case that the two treatment groups and the control group exhibit common trends. In other words, there should not exist time trends that are specific to the control group and are different from that of the treatment group. This

\footnotetext{
19 Based on a difference-in-differences point estimate obtained from an analysis that pools all lower-deciles into one treatment variable, I calculated how much of the rise in the graduation gap between minorities and non-minorities can be explained by the change in admissions policies from affirmative action to the Top $10 \%$ Plan. This calculation was performed as follows:

$$
\left[\left(\overline{\mathrm{G}}_{\mathrm{m}}^{\mathrm{Top} 10}-\overline{\mathrm{G}}_{\mathrm{m}}^{\mathrm{AA}}\right)-\left(\overline{\mathrm{G}}_{\mathrm{nm}}^{\mathrm{Top} 10}-\overline{\mathrm{G}}_{\mathrm{nm}}^{\mathrm{AA}}\right)\right]=\frac{-0.045}{[(0.39-0.42)-(0.69-0.67)]}=\frac{-0.045}{(-0.03-0.02)}=0.90
$$

where $\hat{\beta}_{\mathrm{m}}^{\text {grad }}$ is an estimated coefficient obtained from regressing minority graduation within six-years on a constant, Post x Non-Top10\% Decile dummy, Non-Top10\% Decile (11-100\% percentile class rank) dummy, cohort dummies, student and high school controls (regression standard errors were clustered by students high school). $\bar{G}_{m}^{A A}$ and $\bar{G}_{m}^{\text {Top10 }}$ indicate the mean six-year graduation rate of admitted minority students under affirmative action and the Top $10 \%$ Plan, respectively. Lastly, $\overline{\mathrm{G}}_{\mathrm{nm}}^{\mathrm{AA}}$ and $\overline{\mathrm{G}}_{\mathrm{nm}}^{\mathrm{Top} 10}$ indicate the mean six-year graduation rate of admitted non-minority students under affirmative action and the Top 10\% Plan, respectively.
} 
assumption implies that the $\beta_{k}$ 's in equation (1) are capturing the secular trends that are common to both the treatment groups and the control group.

In this section I conduct a robustness check to establish the case for the parallel trends assumption in the analytic sample. The following model specification allows the differences in the treatment groups with respect to the control group to vary during the period prior to the implementation of the Top 10\% Plan. Hence, this robustness test drops all post-policy observations from the analysis and the two treatment variables are interacted with all pre-policy cohort indicators except for 1993, which serves as the base cohort. ${ }^{20}$ The following model specification is estimated by OLS,

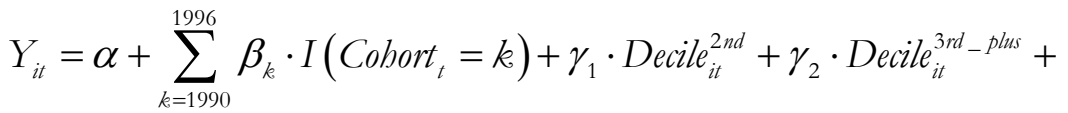

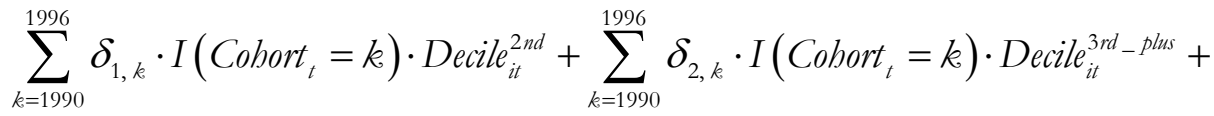

$$
\begin{aligned}
& S_{i t} \cdot \phi+H S_{i t} \cdot \psi+\varphi+\varepsilon_{i t}
\end{aligned}
$$

All of the variables in equation (2) have the same meaning as previously defined; however, the coefficients of interest are now $\delta_{1, k}$ and $\delta_{2, k}(k=1990, \ldots, 1996)$, which indicate any differences in the yearly cohort effect of the treatment groups (i.e., second and lower deciles) with respect to the comparison year (i.e., 1993).

If the earlier difference-in-differences point estimates are estimating the causal effect of the Top 10\% Plan, then we should expect there to be no statistically significant differences between the treatment groups and the control group in the pre-policy years.

\footnotetext{
${ }^{20}$ An alternative test for the parallel trends assumption was also conducted. Specifically, I dropped all postpolicy cohorts (i.e., 1998 and 1999 cohorts) and redefined the "post" variable as a "fake cohort" (i.e., 1993
} 
Table 5 presents the results of this analysis for the minority sample, and only the coefficients of interest are reported. The coefficients of the interaction terms in these models are subsequently tested in two ways: if the coefficients are jointly significant and if they are equal to each other. At the bottom of Table 5, the F-statistics indicate that these coefficients are jointly statistically insignificant and that the coefficients are equal to each other. ${ }^{21}$ Thus, these tests establish the case that the parallel trends assumption holds for the analytic sample and reinforces the identification strategy implemented in this paper.

\section{Conclusion}

This paper informs the ongoing national debate on affirmative action policies in higher education and provides new evidence on the effects of alternative admissions policies, specifically the top x-percent plans, on college persistence and completion of minority students. In light of the changing legal status of race-sensitive admissions policies in higher education, it is important to understand the merits of alternative admissions policies, especially since states like Texas, California, and Florida that banned the use of race-based preferences in postsecondary admissions have implemented some form of rank-based admissions. The Texas Top 10\% Plan provides an important experimental setting in which the effects of this policy change on the college outcomes of non-top x-percent students at public institutions can be examined.

I find that the change from affirmative action admissions policies to the Top $10 \%$ Plan in Texas decreased both college persistence and completion rates of lower-ranked

cohort), choosing a cohort that was admitted when the Top 10\% Plan was not in effect. All of the differencein-differences point estimates from this alternative estimation were statistically insignificant for both outcomes.

21 The same analysis and F-tests were conducted for the non-minority sample. In all model specifications, the F-statistics indicated that the coefficients of the interaction terms are jointly statistically insignificant and the 
minority students. Freshmen retention and six-year college graduation rates of second-decile minority students decreased, respectively, by 2.4 and 3.3 percentage points. The effect of this policy change was slightly larger for minority students in the third and below deciles: freshmen retention and six-year college graduation rates decreased, respectively, by 4.9 and 4.2 percentage points.

Contrary to critics of race-sensitive admissions, results from the analysis run counter to the "mismatch" hypothesis, which would have predicted both higher retention and college graduation rates for these lower-ranked minority students because they are now supposedly being better "matched" to an institution under the Top 10\% Plan. Moreover, while I find that the postsecondary educational attainment of minority students declined under the Top $10 \%$ Plan admissions policy, interestingly, the elimination of affirmative action policies did not increase college retention or graduation for non-minority students under the postaffirmative action era. The analysis suggests that elimination of racial preference in college admissions in Texas did not help non-minorities as much as it harmed the retention and graduation of minority students.

coefficients are equal to each other, indicating that the parallel trends assumption also holds for the nonminority analytic sample. 


\section{References}

Alon, Sigal and Marta Tienda (2005). "Assessing the 'Mismatch' Hypothesis: Differences in College Graduation Rates by Institutional Selectivity." Sociology of Education 78, 294-315.

Ayres, Ian and Richard Brooks (2005). "Does Affirmative Action Reduce the Number of Black Lawyers?” Stanford Law Review 57, 1807-1854.

Barron's College Division (2002), Barron's Profiles of American Colleges: $25^{\text {th }}$ Edition 2003 (Hauppauge, NY: Barron's Educational Series, Inc.).

Black, Daniel A. and Jeffrey A. Smith (2004). "How Robust is the Evidence on the Effects of College Quality? Evidence from Matching." Journal of Econometrics 121, 99-124.

Bowen, William G. and Derek Bok (1998). The Shape of the River: Long-term Consequences of Considering Race in College and University Admissions (Princeton, N.J.: Princeton University Press).

Brewer, Dominic J. and Ronald G. Ehrenberg (1996). "Does It Pay to Attend an Elite Private College? Evidence from the Senior High School Class of 1980” (pp. 239-271), in Solomon Polacheck (Ed.), Research in Labor Economics, Volume 15 (JAI Press, Greenwich, CT).

Brewer, Dominic. J., Eric R. Eide, and Ronald G. Ehrenberg (1999). "Does It Pay to Attend an Elite Private College? Cross-Cohort Evidence on the Effects of College Type on Earnings." Journal of Human Resources 34, 104-23.

Bucks, Brian (2004). "Affirmative Access versus Affirmative Action: How Have Texas' Race-Blind Policies Affected College Outcomes?” Unpublished manuscript, University of Texas at Dallas.

Card, David and Alan B. Krueger (2005). "Would the Elimination of Affirmative Action Affect Highly Qualified Minority Applicants? Evidence from California and Texas." Industrial \& Labor Relations Review 58(3), 416-34.

Cortes, Kalena E. and Andrew I. Friedson (2010). "Ranking Up by Moving Out: The Effect of the Texas Top 10\% Plan on Property Values." Unpublished manuscript, Syracuse University.

Cullen, Julie, Randall Reback, and Mark Long (2009). "Jockeying for a Position: High School Student Mobility and the Texas Top-Ten Percent Rule," Unpublished manuscript, University of California, San Diego.

Dee, Thomas S. (2004). "Are There Civic Returns to Education?" Journal of Public Economics 88(9), 697-1720.

Dickson, Lisa M. (2006). "Does Ending Affirmative Action in College Admissions Lower the Percent of Minority Students Applying to College?" Economics of Education Review 25(1), 109-19.

Faulkner, L. R. (2000). “Top 10 Percent' Helps Students.” San Antonio ExpressNews, pg. 5B, October 25.

Fischer, Mary J. and Douglas S. Massey (2007). "The Effects of Affirmative Action in Higher Education.” Social Science Research 36, 531-549.

Graglia, Lino A. (1993). "Racial Preferences in Admission to Institutions of Higher Education" (pp. 127-51), in Howard Dickman (Ed.), The Imperiled Academy (New Brunswick, NJ: Transaction Publishers). 
Ho, Daniel E. (2005). "Why Affirmative Action Does Not Cause Black Students to Fail the Bar," Yale Law Journal 114, 1997-2004.

Hockstader, L. (2002). “Texas Colleges' Diversity Plan May Be New Model.” The Washington Post, pg. A01, November 4.

Hopwood v. University of Texas 78 F.3d 932, 944 (5th Cir. 1996), cert. denied, 116 S.Ct. 2582, 1996.

Horn, Catherine L. and Stella M. Flores (2003). "Percent Plans in College Admissions: A Comparative Analysis of Three States' Experiences." Cambridge, MA: Civil Rights Project at Harvard University.

Jenks, George F. (1967). "The Data Model Concept in Statistical Mapping," International Yearbook of Cartography 7, 86-190.

Kane, Thomas J. (1998a). "Misconceptions in the Debate over Affirmative Action in College Admissions" (pp. 17-32), in Gary Orfield and Edward Miller (Eds.), Chilling Admissions: The Affirmative Crisis and the Search for Alternatives (Cambridge: Harvard Education Publishing Group).

Kane, Thomas J. (1998b). "Racial and Ethnic Preferences in College Admission" (pp. 431-56), in C. Jencks and M. Phillips (Eds.), The Black-White Test Score Gap (Washington, D.C.: Brookings Institution Press).

Kane, Thomas J., and William T. Dickens (1996). "Racial and Ethnic Preference." Policy Brief No. 9, Brookings Institution.

Leicht, K. T. and Teresa A. Sullivan (2000). "Minority Student Pipelines Before and After the Challenges to Affirmative Action." Unpublished manuscript, University of Iowa.

Loury, Linda D. and David Garman (1993). "Affirmative Action in Higher Education." American Economic Review 83(2), 99-103.

Loury, Linda D. and David Garman (1995). "College Selectivity and Earnings." Journal of Labor Economics 13(2), 289-308.

Niu, Sunny, Marta Tienda, and Kalena E. Cortes (2006). "College Selectivity and the Texas Top 10\% Law: How Constrained are the Options?” Economics of Education Review 25(3), 259-27.

Rothstein, Jesse and Albert Yoon (2006). "Mismatch in Law School." Education Research Section Working Paper No. 16, Princeton University, Department of Economics, February.

Sander, Richard (2004). "A Systematic Analysis of Affirmative Action in American Law Schools," Stanford Law Review 57, 367-483.

Thernstrom, Stephan and Abigail Thernstrom (1997). America in Black and White: One Nation Indivisible (New York: Simon \& Schuster).

Thernstrom, Stephan and Abigail Thernstrom (1999). "Reflections on The Shape of the River Book Review." UCLA Law Review 46, 1583-1631.

Tienda, Marta, Kevin T. Leicht, Teresa A. Sullivan, Michael Maltese, and Kim Lloyd (2003). "Closing the Gap?: Admissions and Enrollments at the Texas Public Flagships Before and After Affirmative Action." Working Paper 2003-1, Princeton University Office of Population Research.

U.S. Department of Education, National Center for Education Statistics, Higher Education General Information Survey (2005). "Degrees and Other Formal Awards Conferred" surveys, 1976-77 through 1984-85; and 1988-89 through 2003-04 Integrated 
Postsecondary Education Data System, "Completions Survey" (IPEDS-C:89-99), and Fall 2000 through Fall 2004.

Walker, B. and Lavergne, G. (2001). "Affirmative Action and Percent Plans: What We Learned from Texas." The College Board Review, 193, 18-23.

Yardley, J. (2002). "Desperately Seeking Diversity: The 10 Percent Solution." The New York Times, Education Life Supplement, Section 4A, pg. 28, April 14. 
Figure 1. Location of THEOP Universities and Minority Populations
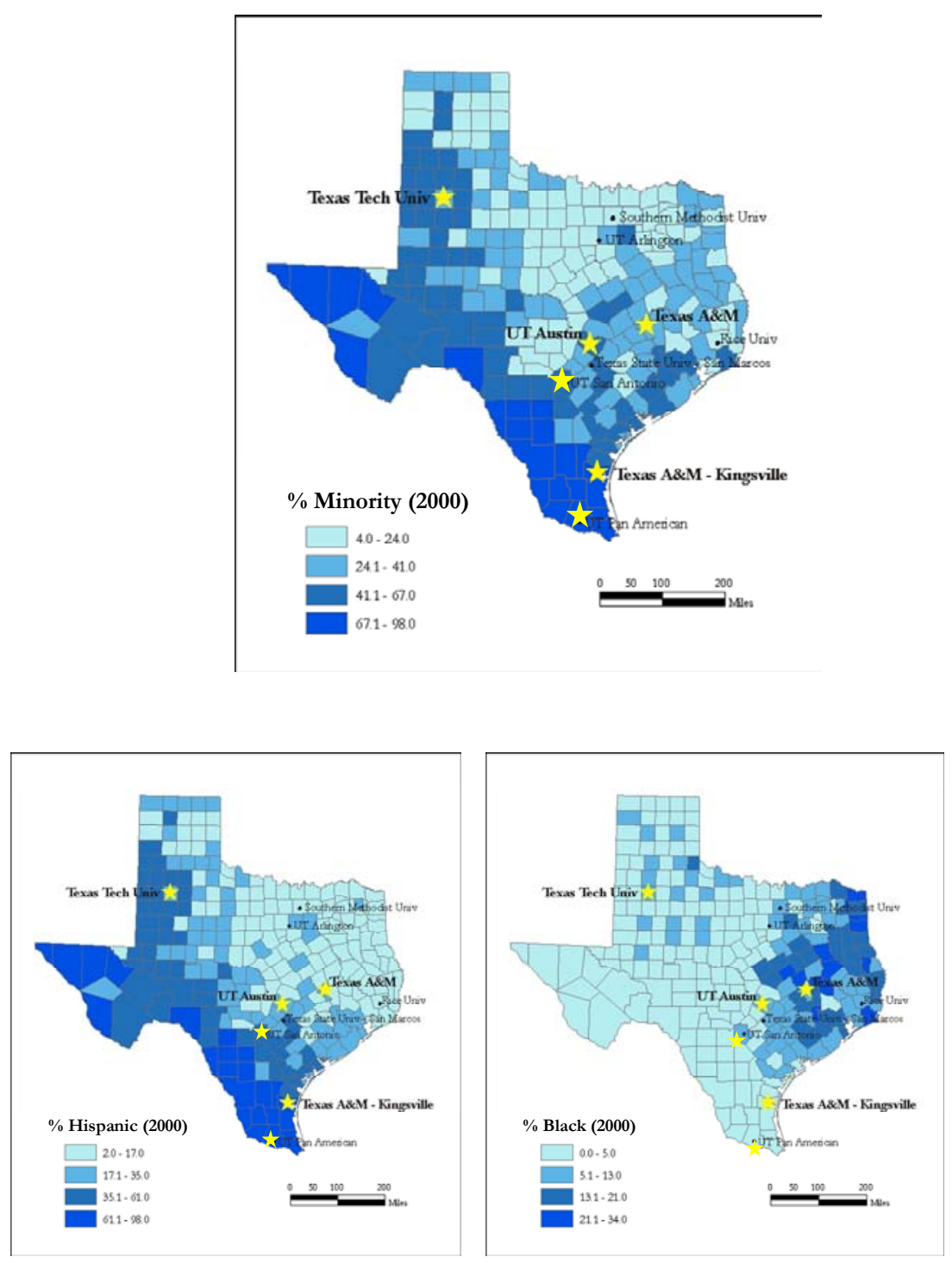

Source: 2000 U.S. Census.

Notes: Maps generated using ArcView. 
Table 1. Admission Rates at UT-Austin or Texas A\&M by Admissions Policy and High School Class Rank (Applicant Sample)

\begin{tabular}{|c|c|c|c|c|}
\hline \multirow[b]{2}{*}{ Panel A: All Students } & \multicolumn{2}{|c|}{ Admission Rates } & \multicolumn{2}{|c|}{ Column Difference (2)-(1): } \\
\hline & $\begin{array}{c}\text { (1) Affirmative Action: } \\
1990 \text { to } 1996\end{array}$ & $\begin{array}{l}\text { (2) Top 10\% Plan: } \\
1998 \text { to } 1999 \\
\end{array}$ & $\begin{array}{c}\text { (3) No } \\
\text { Controls }\end{array}$ & $\begin{array}{l}\text { (4) With } \\
\text { Controls }^{a}\end{array}$ \\
\hline Top 10\% Decile & 0.961 & 0.974 & $\begin{array}{l}0.014^{* * *} \\
(0.002)\end{array}$ & $\begin{array}{l}0.005^{* * *} \\
(0.001)\end{array}$ \\
\hline Second Decile (11-20\%ile class rank) & 0.807 & 0.857 & $\begin{array}{l}0.050 \\
(0.004)\end{array}$ & $\begin{array}{l}0.023^{* * *} \\
(0.004)\end{array}$ \\
\hline \multirow[t]{3}{*}{ Third and Below Deciles (21-100\%ile class rank) } & 0.465 & 0.519 & $\begin{array}{l}0.054^{* * *} \\
(0.005)\end{array}$ & $\begin{array}{l}0.036^{* * *} \\
(0.005)\end{array}$ \\
\hline & 0.755 & 0.783 & $\begin{array}{l}0.028^{* * *} \\
(0.002)\end{array}$ & $\begin{array}{l}0.016^{* * *} \\
(0.002)\end{array}$ \\
\hline & {$[\mathrm{N}=127,559]$} & {$[\mathrm{N}=45,783]$} & & \\
\hline \multicolumn{5}{|l|}{ Panel B: Minority Students } \\
\hline Top 10\% Decile & 0.961 & 0.946 & $\begin{array}{l}-0.015^{* * *} \\
(0.004)\end{array}$ & $\begin{array}{l}-0.007 \\
(0.004)\end{array}$ \\
\hline Second Decile (11-20\%ile class rank) & 0.843 & 0.741 & $\begin{array}{l}-0.102^{* * *} \\
(0.010)\end{array}$ & $\begin{array}{l}-0.117^{* * *} \\
(0.011)\end{array}$ \\
\hline Third and Below Deciles (21-100\%ile class rank) & 0.541 & 0.397 & $\begin{array}{l}-0.144^{* * *} \\
(0.010)\end{array}$ & $\begin{array}{l}-0.168^{* * *} \\
(0.010)\end{array}$ \\
\hline Overall & 0.787 & 0.705 & $\begin{array}{l}-0.082^{* * *} \\
(0.005)\end{array}$ & $\begin{array}{l}-0.078^{* * *} \\
(0.005)\end{array}$ \\
\hline & {$[\mathrm{N}=25,823]$} & {$[\mathrm{N}=8,800]$} & & \\
\hline \multicolumn{5}{|l|}{ Panel C: Non-minority Students } \\
\hline Top 10\% Decile & 0.961 & 0.982 & $\begin{array}{l}0.021^{* * *} \\
(0.002)\end{array}$ & $\begin{array}{l}0.008^{\text {*** }} \\
(0.001)\end{array}$ \\
\hline Second Decile (11-20\%ile class rank) & 0.798 & 0.882 & $\begin{array}{l}0.084^{* * *} \\
(0.005)\end{array}$ & $\begin{array}{l}0.053^{* * *} \\
(0.004)\end{array}$ \\
\hline \multirow[t]{3}{*}{ Third and Below Deciles (21-100\%ile class rank) } & 0.445 & 0.547 & $\begin{array}{l}0.102^{* * *} \\
(0.005)\end{array}$ & $\begin{array}{l}0.081^{* * *} \\
(0.005)\end{array}$ \\
\hline & 0.747 & 0.801 & $\begin{array}{l}0.054^{* * *} \\
(0.003)^{2}\end{array}$ & $\begin{array}{l}0.037^{* * *} \\
(0.002)\end{array}$ \\
\hline & {$[\mathrm{N}=101,736]$} & {$[\mathrm{N}=36,983]$} & & \\
\hline
\end{tabular}

Source: Texas Higher Education Opportunity Project (THEOP), Administrative Data Component.

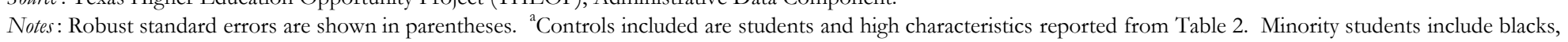
Hispanics, and Native Americans. Non-minority students include non-Hispanic whites and Asians. 
Table 2. Variable Description and Summary Statistics of Enrollees by Admissions Policy and College Selectivity (Means/S.D.)

\begin{tabular}{|c|c|c|c|c|c|c|c|}
\hline \multirow[b]{2}{*}{ Variables } & \multirow{2}{*}{$\begin{array}{l}\text { Panel A: } \\
\text { (1) Full Sample } \\
\end{array}$} & \multicolumn{3}{|c|}{$\begin{array}{l}\text { Panel B: Affirmative Action } \\
\end{array}$} & \multicolumn{3}{|c|}{ Panel C: Top 10\% Plan } \\
\hline & & (2) Sub-Sample & (3) Selective ${ }^{a}$ & (4) Less Selective ${ }^{b}$ & (5) Sub-Sample & (6) Selective ${ }^{a}$ & (7) Less Selective ${ }^{b}$ \\
\hline \multicolumn{8}{|l|}{ Student Characteristics } \\
\hline Scholastic Aptitude Test (SAT) Score & $\begin{array}{l}1108.56 \\
(174.01)\end{array}$ & $\begin{array}{l}1110.34 \\
(170.92)\end{array}$ & $\begin{array}{c}1168.42 \\
(139.70)\end{array}$ & $\begin{array}{l}980.07 \\
(162.55)\end{array}$ & $\begin{array}{l}1104.18 \\
(181.35)\end{array}$ & $\begin{array}{l}1170.07 \\
(144.27)\end{array}$ & $\begin{array}{l}978.74 \\
(178.52)\end{array}$ \\
\hline High School Percentile Class Rank & $\begin{array}{c}20.22 \\
(18.61)\end{array}$ & $\begin{array}{l}19.84 \\
(18.31)\end{array}$ & $\begin{array}{l}14.61 \\
(13.53)\end{array}$ & $\begin{array}{l}31.55 \\
(21.86)\end{array}$ & $\begin{array}{l}21.18 \\
(19.29)\end{array}$ & $\begin{array}{l}15.35 \\
(14.15)\end{array}$ & $\begin{array}{l}32.28 \\
(22.62)\end{array}$ \\
\hline Black & 0.038 & 0.039 & 0.042 & 0.031 & 0.035 & 0.033 & 0.038 \\
\hline Hispanic & 0.215 & 0.211 & 0.143 & 0.362 & 0.225 & 0.117 & 0.430 \\
\hline Native American & 0.004 & 0.004 & 0.004 & 0.003 & 0.004 & 0.005 & 0.003 \\
\hline Asian & 0.073 & 0.071 & 0.095 & 0.018 & 0.077 & 0.107 & 0.020 \\
\hline Non-Hispanic White & 0.671 & 0.676 & 0.715 & 0.587 & 0.659 & 0.738 & 0.508 \\
\hline Female & 0.506 & 0.501 & 0.494 & 0.516 & 0.519 & 0.518 & 0.521 \\
\hline \multicolumn{8}{|l|}{ High School Characteristics } \\
\hline Mean SAT & $\begin{array}{c}1012.83 \\
(78.00)\end{array}$ & $\begin{array}{r}1012.50 \\
(78.20)\end{array}$ & $\begin{array}{r}1023.35 \\
(73.22)\end{array}$ & $\begin{array}{c}988.18 \\
(83.37)\end{array}$ & $\begin{array}{r}1013.65 \\
(77.49)\end{array}$ & $\begin{array}{r}1028.68 \\
(71.06)\end{array}$ & $\begin{array}{l}985.05 \\
(81.09)\end{array}$ \\
\hline \% Free Lunch Eligible Students & $\begin{array}{c}20.77 \\
(18.93)\end{array}$ & $\begin{array}{l}20.47 \\
(18.89)\end{array}$ & $\begin{array}{l}16.92 \\
(15.70)\end{array}$ & $\begin{array}{l}28.43 \\
(22.65)\end{array}$ & $\begin{array}{l}21.50 \\
(19.00)\end{array}$ & $\begin{array}{l}16.40 \\
(14.80)\end{array}$ & $\begin{array}{l}31.20 \\
(22.09)\end{array}$ \\
\hline$\%$ Minority Students & $\begin{array}{c}44.07 \\
(27.13)\end{array}$ & $\begin{array}{l}43.21 \\
(26.90)\end{array}$ & $\begin{array}{l}39.19 \\
(24.76)\end{array}$ & $\begin{array}{l}52.21 \\
(29.24)\end{array}$ & $\begin{array}{l}46.20 \\
(27.58)\end{array}$ & $\begin{array}{l}39.80 \\
(24.08)\end{array}$ & $\begin{array}{l}58.38 \\
(29.63)\end{array}$ \\
\hline Feeder High School & 0.194 & 0.192 & 0.241 & 0.082 & 0.198 & 0.266 & 0.067 \\
\hline Location & & & & & & & \\
\hline Urban & 0.441 & 0.456 & 0.461 & 0.445 & 0.404 & 0.386 & 0.438 \\
\hline Suburban & 0.315 & 0.296 & 0.319 & 0.245 & 0.362 & 0.409 & 0.272 \\
\hline Town & 0.147 & 0.162 & 0.139 & 0.214 & 0.111 & 0.087 & 0.156 \\
\hline Rural & 0.096 & 0.085 & 0.081 & 0.096 & 0.124 & 0.118 & 0.135 \\
\hline $\begin{array}{r}\text { Total Sample } \\
\text { Minority Sample } \\
\text { Non-minority Sample }\end{array}$ & $\begin{array}{c}120,452 \\
30,868 \\
89,584\end{array}$ & 85,752 & 59,306 & 26,446 & 34,700 & 22,749 & 11,951 \\
\hline
\end{tabular}

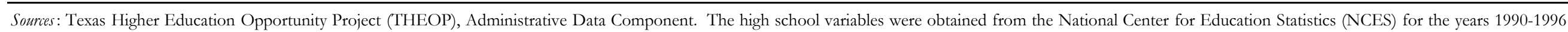
and 1998-1999, with the exception of the mean high school SAT variable, which was obtained from the College Board and is based on all Texas students who took the SAT in 1996.

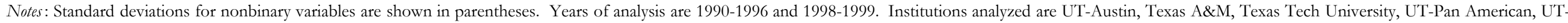

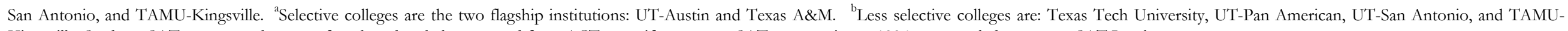
Kingsville. Students SAT scores are the sum of math and verbal, converted from ACT score if necessary. SAT scores prior to 1996 are re-scaled to current SAT I scale. 
Table 3A. Unadjusted Difference-in-Differences Estimates: Minority Students

\begin{tabular}{|c|c|c|c|}
\hline & \multicolumn{2}{|c|}{ Panel A: Freshmen Retention } & \multirow[b]{2}{*}{$\begin{array}{c}\text { Column } \\
\text { Difference }\end{array}$} \\
\hline & $\begin{array}{c}\text { Affirmative Action: } \\
1990 \text { to } 1996\end{array}$ & $\begin{array}{c}\text { Top } 10 \% \text { Plan: } \\
1998 \text { to } 1999\end{array}$ & \\
\hline Top 10\% Decile & 0.844 & 0.872 & $\begin{array}{c}0.028^{* * *} \\
(0.009)\end{array}$ \\
\hline Second Decile (11-20\%ile class rank) & 0.780 & 0.782 & $\begin{array}{c}0.002 \\
(0.012)\end{array}$ \\
\hline Third and Below Deciles (21-100\%ile class rank) & 0.633 & 0.593 & $\begin{array}{c}-0.040 * * * \\
(0.013)\end{array}$ \\
\hline Difference: Top $10 \%$ and Second decile & $\begin{array}{c}-0.064 * * * \\
(0.008)\end{array}$ & $\begin{array}{c}-0.090 * * * \\
(0.013)\end{array}$ & $\begin{array}{l}-0.026^{*} \\
(0.016)\end{array}$ \\
\hline Difference: Top $10 \%$ and Third plus deciles & $\begin{array}{c}-0.212^{* * *} \\
(0.007)\end{array}$ & $\begin{array}{c}-0.279 * * * \\
(0.010)\end{array}$ & $\begin{array}{c}-0.067 * * * \\
(0.012)\end{array}$ \\
\hline
\end{tabular}

Panel B: Graduate within 6 years

\begin{tabular}{|c|c|c|c|}
\hline & $\begin{array}{c}\text { Affirmative Action: } \\
1990 \text { to } 1996\end{array}$ & $\begin{array}{c}\text { Top } 10 \% \text { Plan: } \\
1998 \text { to } 1999 \\
\end{array}$ & $\begin{array}{c}\text { Column } \\
\text { Difference }\end{array}$ \\
\hline Top 10\% Decile & 0.609 & 0.635 & $\begin{array}{c}0.026^{* *} \\
(0.012)\end{array}$ \\
\hline Second Decile (11-20\%ile class rank) & 0.478 & 0.471 & $\begin{array}{l}-0.007 \\
(0.014)\end{array}$ \\
\hline Third and Below Deciles (21-100\%ile class rank) & 0.266 & 0.223 & $\begin{array}{c}-0.043 * * * \\
(0.010)\end{array}$ \\
\hline Difference: Top 10\% and Second decile & $\begin{array}{c}-0.131 * * * \\
(0.009)\end{array}$ & $\begin{array}{c}-0.164 * * * \\
(0.014)\end{array}$ & $\begin{array}{c}-0.034^{* *} \\
(0.017)\end{array}$ \\
\hline Difference: Top $10 \%$ and Third plus deciles & $\begin{array}{c}-0.343^{* * *} \\
(0.007)\end{array}$ & $\begin{array}{c}-0.412^{* * *} \\
(0.011)\end{array}$ & $\begin{array}{c}-0.069 * * * \\
(0.013)\end{array}$ \\
\hline
\end{tabular}

Source: Texas Higher Education Opportunity Project (THEOP), Administrative Data Component.

Notes: All standard errors (shown in parentheses) are clustered at the high school level. Number of observations are 30,868. Minority students include blacks, Hispanics, and Native Americans. ***, **, * indicates statistical significance at the 1\%, 5\%, and 10\% level, respectively. 
Table 3B. Unadjusted Difference-in-Differences Estimates: Non-minority Students

\begin{tabular}{|c|c|c|c|}
\hline & \multicolumn{2}{|c|}{ Panel A: Freshmen Retention } & \multirow[b]{2}{*}{$\begin{array}{l}\text { Column } \\
\text { Difference }\end{array}$} \\
\hline & $\begin{array}{c}\text { Affirmative Action: } \\
1990 \text { to } 1996\end{array}$ & $\begin{array}{c}\text { Top 10\% Plan: } \\
1998 \text { to } 1999\end{array}$ & \\
\hline Top 10\% Decile & 0.925 & 0.936 & $\begin{array}{c}0.011^{* * *} \\
(0.003)\end{array}$ \\
\hline Second Decile (11-20\%ile class rank) & 0.870 & 0.885 & $\begin{array}{c}0.015^{* *} \\
(0.006)\end{array}$ \\
\hline Third and Below Deciles (21-100\%ile class rank) & 0.754 & 0.791 & $\begin{array}{c}0.036 * * * \\
(0.007)\end{array}$ \\
\hline Difference: Top $10 \%$ and Second decile & $\begin{array}{c}-0.055^{* * *} \\
(0.003)\end{array}$ & $\begin{array}{c}-0.051 * * * \\
(0.005)\end{array}$ & $\begin{array}{c}0.004 \\
(0.006)\end{array}$ \\
\hline Difference: Top $10 \%$ and Third plus deciles & $\begin{array}{c}-0.171 \text { *** } \\
(0.003)\end{array}$ & $\begin{array}{c}-0.145^{* * *} \\
(0.005)\end{array}$ & $\begin{array}{c}0.025^{* * *} * \\
(0.006)\end{array}$ \\
\hline
\end{tabular}

Panel B: Graduate within 6 years

\begin{tabular}{|c|c|c|c|}
\hline & $\begin{array}{c}\text { Affirmative Action: } \\
1990 \text { to } 1996\end{array}$ & $\begin{array}{c}\text { Top } 10 \% \text { Plan: } \\
1998 \text { to } 1999 \\
\end{array}$ & $\begin{array}{c}\text { Column } \\
\text { Difference }\end{array}$ \\
\hline Top 10\% Decile & 0.789 & 0.817 & $\begin{array}{c}0.028^{* * *} \\
(0.005)\end{array}$ \\
\hline Second Decile (11-20\%ile class rank) & 0.681 & 0.698 & $\begin{array}{c}0.017 * * \\
(0.007)\end{array}$ \\
\hline Third and Below Deciles (21-100\%ile class rank) & 0.508 & 0.543 & $\begin{array}{c}0.035^{* * *} \\
(0.009)\end{array}$ \\
\hline Difference: Top 10\% and Second decile & $\begin{array}{c}-0.108^{* * *} \\
(0.005)\end{array}$ & $\begin{array}{c}-0.118^{* * *} \\
(0.007)\end{array}$ & $\begin{array}{l}-0.011 \\
(0.009)\end{array}$ \\
\hline Difference: Top 10\% and Third plus deciles & $\begin{array}{c}-0.281 * * * \\
(0.004)\end{array}$ & $\begin{array}{c}-0.274 * * * \\
(0.007)\end{array}$ & $\begin{array}{c}0.007 \\
(0.008)\end{array}$ \\
\hline
\end{tabular}

Source: Texas Higher Education Opportunity Project (THEOP), Administrative Data Component.

Notes: All standard errors (shown in parentheses) are clustered at the high school level. Number of observations are 89,584. Nonminority students include non-Hispanic whites and Asians. ***, ** indicates statistical significance at the $1 \%$ and $5 \%$ level, respectively. 
Table 4A. The Effect of the Top 10\% Plan on College Persistence and Completion: Difference-in-Differences Regressions for Minority Students

\begin{tabular}{|c|c|c|c|c|c|c|c|c|}
\hline & \multicolumn{4}{|c|}{ Panel A: Freshmen Retention } & \multicolumn{4}{|c|}{ Panel B: Graduate within 6 years } \\
\hline & Model 1 & Model 2 & Model 3 & Model 4 & Model 1 & Model 2 & Model 3 & Model 4 \\
\hline Post x Second Decile & $\begin{array}{c}-0.02288^{*} \\
(0.0130)\end{array}$ & $\begin{array}{c}-0.0228 \text { * } \\
(0.0130)\end{array}$ & $\begin{array}{c}-0.0238^{*} \\
(0.0128)\end{array}$ & $\begin{array}{l}-0.0276^{* *} \\
(0.0135)\end{array}$ & $\begin{array}{l}-0.0322^{* *} \\
(0.0159)\end{array}$ & $\begin{array}{l}-0.0333^{\text {** }} \\
(0.0156)\end{array}$ & $\begin{array}{l}-0.0332^{* *} \\
(0.0154)\end{array}$ & $\begin{array}{l}-0.0265^{*} \\
(0.0156)\end{array}$ \\
\hline Post $\mathrm{x}$ Third and Below Deciles & $\begin{array}{l}-0.0646^{* * *} \\
(0.0139)\end{array}$ & $\begin{array}{l}-0.0518^{* * *} \\
(0.0133)\end{array}$ & $\begin{array}{l}-0.0491^{* * *} \\
(0.0130)\end{array}$ & $\begin{array}{l}-0.0557^{\text {*** }} \\
(0.0132)\end{array}$ & $\begin{array}{l}-0.0691^{\text {*** }} \\
(0.0153)\end{array}$ & $\begin{array}{l}-0.0499^{* * *} \\
(0.0140)\end{array}$ & $\begin{array}{l}-0.0418 \\
(0.0138)\end{array}$ & $\begin{array}{c}-0.0400^{\text {*** }} \\
(0.0138)\end{array}$ \\
\hline Second Decile (11-20\%ile class rank) & $\begin{array}{l}-0.0635^{\text {*** }} \\
(0.0083)\end{array}$ & $\begin{array}{l}-0.0357^{\text {*** }} \\
(0.0080)\end{array}$ & $\begin{array}{l}-0.0589^{* * *} \\
(0.0081)\end{array}$ & $\begin{array}{l}-0.0646^{* * *} \\
(0.0081)\end{array}$ & $\begin{array}{l}-0.1299^{* * *} \\
(0.0113)\end{array}$ & $\begin{array}{l}-0.0841 \\
(0.0107)\end{array}$ & $\begin{array}{l}-0.1242^{* * *} \\
(0.0096)\end{array}$ & $\begin{array}{l}-0.1347^{\text {*** }} \\
(0.0095)\end{array}$ \\
\hline Third and Below Deciles (21-100\%ile class rank) & $\begin{array}{l}-0.2106^{* * *} \\
(0.0106)\end{array}$ & $\begin{array}{l}-0.1267^{\text {*** }} \\
(0.0105)\end{array}$ & $\begin{array}{l}-0.1717^{\text {*** }} \\
(0.0100)\end{array}$ & $\begin{array}{l}-0.1854^{\text {*** }} \\
(0.0091)\end{array}$ & $\begin{array}{l}-0.3408^{\text {*** }} \\
(0.0129)\end{array}$ & $\begin{array}{l}-0.2084^{* * *} \\
(0.0127)\end{array}$ & $\begin{array}{l}-0.2849^{\text {*** }} \\
(0.0106)\end{array}$ & $\begin{array}{l}-0.2980^{\text {*** }} \\
(0.0100)\end{array}$ \\
\hline Constant & $\begin{array}{c}0.8166^{* * *} \\
(0.0109)\end{array}$ & $\begin{array}{r}0.0943 \\
(0.0914)\end{array}$ & $\begin{array}{c}-1.2125^{*} \\
(0.6178)\end{array}$ & $\begin{array}{c}-0.0124 \\
(0.1174)\end{array}$ & 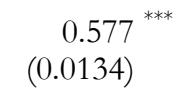 & $\begin{array}{c}-0.16722^{*} \\
(0.0786)\end{array}$ & $\begin{array}{c}-0.3324 \\
(0.6057)\end{array}$ & $\begin{array}{c}0.7016^{\text {*** }} \\
(0.1197)\end{array}$ \\
\hline Cohort Dummies & Yes & Yes & Yes & Yes & Yes & Yes & Yes & Yes \\
\hline Student Characteristics & No & Yes & Yes & Yes & No & Yes & Yes & Yes \\
\hline High School Demographics (time-varying) & No & No & Yes & Yes & No & No & Yes & Yes \\
\hline High School Fixed Effects & No & No & No & Yes & No & No & No & Yes \\
\hline Observations (student-by-year) & 30,868 & 30,868 & 30,868 & 30,868 & 30,868 & 30,868 & 30,868 & 30,868 \\
\hline $\mathrm{R}^{2}$ & 0.06 & 0.09 & 0.11 & 0.15 & 0.11 & 0.18 & 0.20 & 0.24 \\
\hline
\end{tabular}

Source: Texas Higher Education Opportunity Project (THEOP), Administrative Data Component.

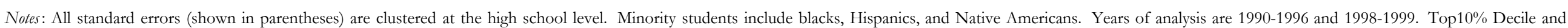

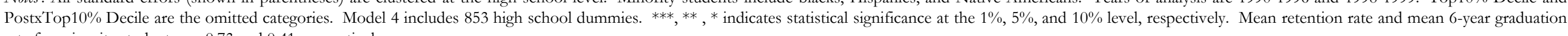
rate for minority students are 0.73 and 0.41 ; respectively. 
Table 4B. The Effect of the Top 10\% Plan on College Persistence and Completion: Difference-in-Differences Regressions for Non-minority Students

\begin{tabular}{|c|c|c|c|c|c|c|c|c|}
\hline & \multicolumn{4}{|c|}{ Panel A: Freshmen Retention } & \multicolumn{4}{|c|}{ Panel B: Graduate within 6 years } \\
\hline & Model 1 & Model 2 & Model 3 & Model 4 & Model 1 & Model 2 & Model 3 & Model 4 \\
\hline Post x Second Decile & $\begin{array}{r}0.0043 \\
(0.0064)\end{array}$ & $\begin{array}{r}0.0065 \\
(0.0063)\end{array}$ & $\begin{array}{r}0.0061 \\
(0.0062)\end{array}$ & $\begin{array}{r}0.0069 \\
(0.0062)\end{array}$ & $\begin{array}{r}-0.0104 \\
(0.0086)\end{array}$ & $\begin{array}{r}-0.0072 \\
(0.0086)\end{array}$ & $\begin{array}{r}-0.0080 \\
(0.0087)\end{array}$ & $\begin{array}{r}-0.0048 \\
(0.0088)\end{array}$ \\
\hline Post $\mathrm{x}$ Third and Below Deciles & $c^{0.0253^{* * *}}$ & ${ }^{0.0240}{ }^{* * *}$ & $c^{0.0236}{ }^{* * *}$ & $c^{0.0239^{* * *}}$ & $\begin{array}{r}0.0062 \\
(0.0093)\end{array}$ & $\begin{array}{r}0.0049 \\
(0.0087)\end{array}$ & $\begin{array}{r}0.0041 \\
(0.0083)\end{array}$ & $\begin{array}{r}0.0054 \\
(0.0082)\end{array}$ \\
\hline Second Decile (11-20\%ile class rank) & $\begin{array}{l}-0.0550^{* * *} \\
(0.0046)\end{array}$ & $\begin{array}{l}-0.0369^{* * *} \\
(0.0044)\end{array}$ & $\begin{array}{l}-0.0555^{\text {*** }} \\
(0.0042)\end{array}$ & $\begin{array}{l}-0.0582^{* * *} \\
(0.0043)\end{array}$ & $\begin{array}{l}-0.1075^{* * *} \\
(0.0067)\end{array}$ & $\begin{array}{l}-0.0811^{* * *} \\
(0.0066)\end{array}$ & $\begin{array}{l}-0.1154^{\text {*** }} \\
(0.0057)\end{array}$ & $\begin{array}{l}-0.1204^{* * *} \\
(0.0058)\end{array}$ \\
\hline Third and Below Deciles (21-100\%ile class rank) & $\begin{array}{l}-0.1700^{\text {*** }} \\
(0.0094)\end{array}$ & $\begin{array}{l}-0.1186^{* * *} \\
(0.0081)\end{array}$ & $\begin{array}{l}-0.1543^{* * *} \\
(0.0063)\end{array}$ & $\begin{array}{l}-0.1580 \\
(0.0061)\end{array}$ & $\begin{array}{l}-0.2795^{* * *} \\
(0.0130)\end{array}$ & $\begin{array}{l}-0.2058^{* * *} \\
(0.0118)\end{array}$ & $\begin{array}{l}-0.2724^{\text {*** }} \\
(0.0075)\end{array}$ & $\begin{array}{l}-0.2781^{* * *} \\
(0.0066)\end{array}$ \\
\hline Constant & $\begin{array}{c}0.9364^{* * *} \\
(0.0037)\end{array}$ & $\begin{array}{l}-0.4446 \\
(0.0969)\end{array}$ & $\begin{array}{l}-1.2867^{\text {*** }} \\
(0.2887)\end{array}$ & $\begin{array}{c}-0.1874^{* *} \\
(0.0903)\end{array}$ & $\begin{array}{c}0.8129^{* * *} \\
(0.0060)\end{array}$ & $\begin{array}{l}-0.9021^{* * *} \\
(0.0892)\end{array}$ & $\begin{array}{l}-1.5455^{\text {*** }} \\
(0.4905)\end{array}$ & $\begin{array}{c}-0.2736 \\
(0.0932)\end{array}$ \\
\hline Cohort Dummies & Yes & Yes & Yes & Yes & Yes & Yes & Yes & Yes \\
\hline Student Characteristics & No & Yes & Yes & Yes & No & Yes & Yes & Yes \\
\hline High School Demographics (time-varying) & No & No & Yes & Yes & No & No & Yes & Yes \\
\hline High School Fixed Effects & No & No & No & Yes & No & No & No & Yes \\
\hline Observations (student-by-year) & 89,584 & 89,584 & 89,584 & 89,584 & 89,584 & 89,584 & 89,584 & 89,584 \\
\hline $\mathrm{R}^{2}$ & 0.04 & 0.07 & 0.08 & 0.11 & 0.07 & 0.10 & 0.12 & 0.15 \\
\hline
\end{tabular}

Source: Texas Higher Education Opportunity Project (THEOP), Administrative Data Component.

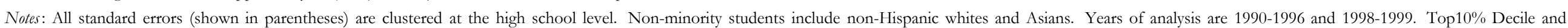

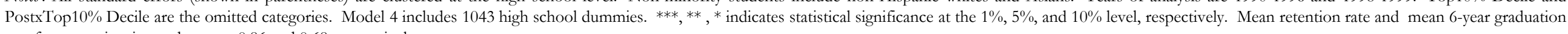
rate for non-minority students are 0.86 and 0.68 ; respectively. 
Table 5. Pre-policy Difference-in-Differences Regressions: Testing the Parallel Trends Assumption (Minority Students)

\begin{tabular}{|c|c|c|c|c|c|c|c|c|}
\hline & \multicolumn{4}{|c|}{ Panel A: Freshmen Retention } & \multicolumn{4}{|c|}{ Panel B: Graduate within 6 years } \\
\hline & Model 1 & Model 2 & Model 3 & Model 4 & Model 1 & Model 2 & Model 3 & Model 4 \\
\hline Cohort 1990 x Second Decile & $\begin{array}{l}-0.017 \\
(0.036)\end{array}$ & $\begin{array}{r}-0.020 \\
(0.035)\end{array}$ & $\begin{array}{l}-0.021 \\
(0.036)\end{array}$ & $\begin{array}{r}-0.017 \\
(0.037)\end{array}$ & $\begin{array}{r}0.007 \\
(0.047)\end{array}$ & $\begin{array}{r}0.005 \\
(0.045)\end{array}$ & $\begin{array}{r}0.003 \\
(0.044)\end{array}$ & $\begin{array}{r}0.003 \\
(0.045)\end{array}$ \\
\hline Cohort 1991 x Second Decile & $\begin{array}{r}0.026 \\
(0.034)\end{array}$ & $\begin{array}{r}0.020 \\
(0.033)\end{array}$ & $\begin{array}{r}0.021 \\
(0.033)\end{array}$ & $\begin{array}{r}0.022 \\
(0.034)\end{array}$ & $\begin{array}{r}0.034 \\
(0.044)\end{array}$ & $\begin{array}{r}0.035 \\
(0.044)\end{array}$ & $\begin{array}{r}0.037 \\
(0.044)\end{array}$ & $\begin{array}{r}0.030 \\
(0.045)\end{array}$ \\
\hline Cohort 1992 x Second Decile & $\begin{array}{r}0.014 \\
(0.026)\end{array}$ & $\begin{array}{r}0.007 \\
(0.026)\end{array}$ & $\begin{array}{r}0.005 \\
(0.025)\end{array}$ & $\begin{array}{r}0.001 \\
(0.026)\end{array}$ & $\begin{array}{r}0.036 \\
(0.038)\end{array}$ & $\begin{array}{r}0.030 \\
(0.036)\end{array}$ & $\begin{array}{r}0.025 \\
(0.036)\end{array}$ & $\begin{array}{r}0.018 \\
(0.036)\end{array}$ \\
\hline Cohort 1994 x Second Decile & $\begin{array}{r}0.015 \\
(0.028)\end{array}$ & $\begin{array}{r}0.019 \\
(0.027)\end{array}$ & $\begin{array}{r}0.019 \\
(0.026)\end{array}$ & $\begin{array}{r}0.018 \\
(0.027)\end{array}$ & $\begin{array}{r}0.006 \\
(0.034)\end{array}$ & $\begin{array}{r}0.016 \\
(0.033)\end{array}$ & $\begin{array}{r}0.015 \\
(0.033)\end{array}$ & $\begin{array}{r}0.019 \\
(0.033)\end{array}$ \\
\hline Cohort 1995 x Second Decile & $\begin{array}{r}0.029 \\
(0.026)\end{array}$ & $\begin{array}{r}0.034 \\
(0.025)\end{array}$ & $\begin{array}{r}0.035 \\
(0.025)\end{array}$ & $\begin{array}{r}0.033 \\
(0.025)\end{array}$ & $\begin{array}{r}0.036 \\
(0.032)\end{array}$ & $\begin{array}{c}0.054^{*} \\
(0.031)\end{array}$ & $\begin{array}{c}0.054^{*} \\
(0.030)\end{array}$ & $\begin{array}{c}0.065^{\text {** }} \\
(0.031)\end{array}$ \\
\hline Cohort 1996 x Second Decile & $\begin{array}{r}0.011 \\
(0.028)\end{array}$ & $\begin{array}{r}0.020 \\
(0.027)\end{array}$ & $\begin{array}{r}0.019 \\
(0.026)\end{array}$ & $\begin{array}{r}0.019 \\
(0.026)\end{array}$ & $\begin{array}{l}-0.013 \\
(0.034)\end{array}$ & $\begin{array}{r}0.012 \\
(0.033)\end{array}$ & $\begin{array}{r}0.008 \\
(0.032)\end{array}$ & $\begin{array}{r}0.019 \\
(0.033)\end{array}$ \\
\hline Cohort $1990 \mathrm{x}$ Third and Below Deciles & $\begin{array}{l}-0.001 \\
(0.033)\end{array}$ & $\begin{array}{l}-0.045 \\
(0.032)\end{array}$ & $\begin{array}{l}-0.047 \\
(0.032)\end{array}$ & $\begin{array}{r}-0.040 \\
(0.032)\end{array}$ & $\begin{array}{c}0.107^{\text {*** }} \\
(0.037)\end{array}$ & $\begin{array}{r}0.021 \\
(0.035)\end{array}$ & $\begin{array}{r}0.014 \\
(0.034)\end{array}$ & $\begin{array}{r}0.017 \\
(0.034)\end{array}$ \\
\hline Cohort 1991 x Third and Below Deciles & $\begin{array}{r}-0.002 \\
(0.030)\end{array}$ & $\begin{array}{r}-0.036 \\
(0.030)\end{array}$ & $\begin{array}{r}-0.044 \\
(0.030)\end{array}$ & $\begin{array}{r}-0.037 \\
(0.030)\end{array}$ & $\begin{array}{c}0.061 \\
(0.036)\end{array}$ & $\begin{array}{r}0.008 \\
(0.034)\end{array}$ & $\begin{array}{l}-0.005 \\
(0.034)\end{array}$ & $\begin{array}{l}-0.005 \\
(0.035)\end{array}$ \\
\hline Cohort 1992 x Third and Below Deciles & $\begin{array}{r}-0.008 \\
(0.024)\end{array}$ & $\begin{array}{r}-0.011 \\
(0.024)\end{array}$ & $\begin{array}{r}-0.012 \\
(0.023)\end{array}$ & $\begin{array}{r}-0.014 \\
(0.024)\end{array}$ & $\begin{array}{r}0.019 \\
(0.026)\end{array}$ & $\begin{array}{r}0.022 \\
(0.024)\end{array}$ & $\begin{array}{r}0.023 \\
(0.024)\end{array}$ & $\begin{array}{r}0.020 \\
(0.024)\end{array}$ \\
\hline Cohort $1994 \mathrm{x}$ Third and Below Deciles & $\begin{array}{l}-0.029 \\
(0.024)\end{array}$ & $\begin{array}{l}-0.030 \\
(0.024)\end{array}$ & $\begin{array}{l}-0.031 \\
(0.023)\end{array}$ & $\begin{array}{l}-0.029 \\
(0.024)\end{array}$ & $\begin{array}{l}-0.001 \\
(0.025)\end{array}$ & $\begin{array}{l}-0.003 \\
(0.024)\end{array}$ & $\begin{array}{l}-0.002 \\
(0.023)\end{array}$ & $\begin{array}{l}-0.002 \\
(0.024)\end{array}$ \\
\hline Cohort 1995 x Third and Below Deciles & $\begin{array}{c}0.016 \\
(0.021)\end{array}$ & $\begin{array}{c}0.020 \\
(0.021)\end{array}$ & $\begin{array}{c}0.028 \\
(0.021)\end{array}$ & $\begin{array}{r}0.021 \\
(0.021)\end{array}$ & $\begin{array}{c}0.003 \\
(0.025)\end{array}$ & $\begin{array}{c}0.015 \\
(0.026)\end{array}$ & $\begin{array}{c}0.027 \\
(0.025)\end{array}$ & $\begin{array}{r}0.024 \\
(0.026)\end{array}$ \\
\hline Cohort $1996 \mathrm{x}$ Third and Below Deciles & $\begin{array}{l}-0.039^{*} \\
(0.023)\end{array}$ & $\begin{array}{r}-0.022 \\
(0.023)\end{array}$ & $\begin{array}{r}-0.019 \\
(0.023)\end{array}$ & $\begin{array}{r}-0.028 \\
(0.022)\end{array}$ & $\begin{array}{r}-0.035 \\
(0.023)\end{array}$ & $\begin{array}{l}-0.001 \\
(0.022)\end{array}$ & $\begin{array}{r}0.005 \\
(0.022)\end{array}$ & $\begin{array}{r}0.000 \\
(0.023)\end{array}$ \\
\hline Second Decile (11-20\%ile class rank) & $\begin{array}{l}-0.065^{* * *} \\
(0.021)\end{array}$ & $\begin{array}{l}-0.048^{* *} \\
(0.021)\end{array}$ & $\begin{array}{l}-0.0699^{* * *} \\
(0.020)\end{array}$ & $\begin{array}{l}-0.0744^{* * *} \\
(0.021)\end{array}$ & $\begin{array}{l}-0.145^{* * *} \\
(0.027)\end{array}$ & $\begin{array}{l}-0.106^{* * *} \\
(0.026)\end{array}$ & $\begin{array}{l}-0.143^{* * *} \\
(0.025)\end{array}$ & $\begin{array}{l}-0.158^{* * *} \\
(0.025)\end{array}$ \\
\hline Third and Below Deciles (21-100\%ile class rank) & $\begin{array}{l}-0.166^{\text {*** }} \\
(0.017)\end{array}$ & $\begin{array}{l}-0.110^{\text {*** }} \\
(0.017)\end{array}$ & $\begin{array}{l}-0.154^{\text {*** }} \\
(0.016)\end{array}$ & $\begin{array}{l}-0.168^{* * *} \\
(0.016)\end{array}$ & $\begin{array}{l}-0.348^{\text {*** }} \\
(0.020)\end{array}$ & $\begin{array}{l}-0.211^{\text {*** }} \\
(0.020)\end{array}$ & $\begin{array}{l}-0.289^{\text {*** }} \\
(0.018)\end{array}$ & $\begin{array}{l}-0.301 \\
(0.019)\end{array}$ \\
\hline Constant & $\begin{array}{l}0.784^{* * *} \\
(0.014)\end{array}$ & $\begin{array}{c}0.090 \\
(0.110)\end{array}$ & $\begin{array}{l}-1.594^{\text {** }} \\
(0.721)\end{array}$ & $\begin{array}{r}0.193 \\
(0.175)\end{array}$ & $\begin{array}{l}0.633^{* * *} \\
(0.018)\end{array}$ & $\begin{array}{l}-0.218^{\text {** }} \\
(0.090)\end{array}$ & $\begin{array}{l}-0.676 \\
(0.658)\end{array}$ & $\begin{array}{c}0.712^{* * *} \\
(0.189)\end{array}$ \\
\hline F-statistic $^{a}$ & 0.91 & 1.12 & 1.46 & 1.18 & 1.93 & 0.46 & 0.52 & 0.74 \\
\hline F-statistic $^{\mathrm{b}}$ & 0.98 & 1.21 & 1.55 & 1.28 & 2.11 & 0.47 & 0.51 & 0.74 \\
\hline Observations (student-by-year) & 21,693 & 21,693 & 21,693 & 21,693 & 21,693 & 21,693 & 21,693 & 21,693 \\
\hline $\mathrm{R}^{2}$ & 0.05 & 0.08 & 0.10 & 0.17 & 0.10 & 0.17 & 0.19 & 0.24 \\
\hline Cohort Dummies & Yes & Yes & Yes & Yes & Yes & Yes & Yes & Yes \\
\hline Student Characteristics & No & Yes & Yes & Yes & No & Yes & Yes & Yes \\
\hline High School Demographics (time-varying) & No & No & Yes & Yes & No & No & Yes & Yes \\
\hline High School Fixed Effects & No & No & No & Yes & No & No & No & Yes \\
\hline
\end{tabular}

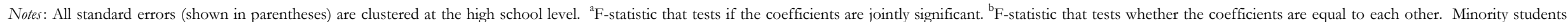

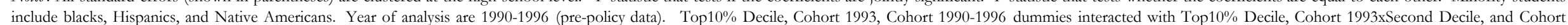
1993xThird and Below Deciles are the omitted categories in all regression specifications. Model 4 includes 796 high school dummies. $* * *$, **, * indicates statistical significance at the $1 \%, 5 \%$, and $10 \%$ level, respectively. 
Appendix Table A1. Difference-in-Differences Regressions: Minority Students (Controls Shown)

\begin{tabular}{|c|c|c|c|c|c|c|c|c|}
\hline & \multicolumn{4}{|c|}{ Panel A: Freshmen Retention } & \multicolumn{4}{|c|}{ Panel B: Graduate within 6 years } \\
\hline & Model 1 & Model 2 & Model 3 & Model 4 & Model 1 & Model 2 & Model 3 & Model 4 \\
\hline Post x Second Decile & $\begin{array}{l}-0.02288^{*} \\
(0.0130)\end{array}$ & $\begin{array}{l}-0.02288^{*} \\
(0.0130)\end{array}$ & $\begin{array}{c}-0.0238^{*} \\
(0.0128)\end{array}$ & $\begin{array}{l}-0.0276^{* *} \\
(0.0135)\end{array}$ & $\begin{array}{l}-0.0322^{* *} \\
(0.0159)\end{array}$ & $\begin{array}{l}-0.0333^{* *} \\
(0.0156)\end{array}$ & $\begin{array}{l}-0.0332^{* *} \\
(0.0154)\end{array}$ & $\begin{array}{l}-0.0265^{*} \\
(0.0156)\end{array}$ \\
\hline Post $x$ Third and Below Deciles & $\begin{array}{l}-0.0646^{* * *} \\
(0.0139)\end{array}$ & $\begin{array}{l}-0.0518^{* * *} \\
(0.0133)\end{array}$ & $\begin{array}{l}-0.0491^{* * *} \\
(0.0130)\end{array}$ & $\begin{array}{l}-0.0557^{\text {*** }} \\
(0.0132)\end{array}$ & $\begin{array}{l}-0.06911^{* * *} \\
(0.0153)\end{array}$ & $\begin{array}{l}-0.0499^{* * *} \\
(0.0140)\end{array}$ & $\begin{array}{l}-0.0418^{\text {*** }} \\
(0.0138)\end{array}$ & $\begin{array}{l}-0.0400 \text { *** } \\
(0.0138)\end{array}$ \\
\hline Second Decile & $\begin{array}{l}-0.0635^{\text {*** }} \\
(0.0083)\end{array}$ & $\begin{array}{l}-0.0357^{* * *} \\
(0.0080)\end{array}$ & $\begin{array}{l}-0.0589^{* * *} \\
(0.0081)\end{array}$ & $\begin{array}{l}-0.0646 \\
(0.0081)\end{array}$ & $\begin{array}{l}-0.1299^{* * *} \\
(0.0113)\end{array}$ & $\begin{array}{l}-0.0841^{* * *} \\
(0.0107)\end{array}$ & $\begin{array}{l}-0.1242^{* * *} \\
(0.0096)\end{array}$ & $\begin{array}{l}-0.1347^{\text {*** }} \\
(0.0095)\end{array}$ \\
\hline Third and Below Deciles & $\begin{array}{l}-0.2106^{* * *} \\
(0.0106) \\
\end{array}$ & $\begin{array}{l}-0.1267^{* * *} \\
(0.0105) \\
\end{array}$ & $\begin{array}{l}-0.1717^{* * *} \\
(0.0100) \\
\end{array}$ & $\begin{array}{l}-0.1854^{* * *} \\
(0.0091)\end{array}$ & $\begin{array}{l}-0.3408^{* * *} \\
(0.0129) \\
\end{array}$ & $\begin{array}{l}-0.2084^{* * *} \\
(0.0127) \\
\end{array}$ & $\begin{array}{l}-0.2849^{* * *} \\
(0.0106) \\
\end{array}$ & $\begin{array}{c}-0.2980 \text { *** } \\
(0.0100)\end{array}$ \\
\hline Black & & $\begin{array}{c}0.06288^{* * *} \\
(0.0094)\end{array}$ & $\begin{array}{c}0.0567^{* * *} \\
(0.0088)\end{array}$ & $\begin{array}{c}0.0450^{* * *} \\
(0.0082)\end{array}$ & & $\begin{array}{c}0.0670^{* * *} \\
(0.0108)\end{array}$ & $\begin{array}{c}0.0454^{* * *} \\
(0.0102)\end{array}$ & $\begin{array}{r}0.0148 \\
(0.0106)\end{array}$ \\
\hline Native American & & $\begin{array}{l}-0.0166 \\
(0.0193)\end{array}$ & $\begin{array}{l}-0.0422^{* *} \\
(0.0188)\end{array}$ & $\begin{array}{l}-0.0580^{* * *} \\
(0.0193)\end{array}$ & & $\begin{array}{r}0.0299 \\
(0.0217)\end{array}$ & $\begin{array}{r}-0.0244 \\
(0.0215)\end{array}$ & $\begin{array}{l}-0.0397^{*} \\
(0.0224)\end{array}$ \\
\hline Female & & $\begin{array}{c}0.0296^{* * *} \\
(0.0051)\end{array}$ & $\begin{array}{c}0.0212^{* * *} \\
(0.0053)\end{array}$ & $\begin{array}{c}0.0178^{* * *} \\
(0.0053)\end{array}$ & & $\begin{array}{c}0.0779^{* * *} \\
(0.0058)\end{array}$ & $\begin{array}{c}0.0644^{* * *} \\
(0.0056)\end{array}$ & $\begin{array}{l}0.0602^{* * *} \\
(0.0055)\end{array}$ \\
\hline SAT (x100) & & $\begin{array}{c}0.0913^{* * *} \\
(0.0171)\end{array}$ & $\begin{array}{c}0.0949^{\text {*** }} \\
(0.0167)\end{array}$ & $\begin{array}{l}0.1159^{\text {*** }} \\
(0.0139)\end{array}$ & & $\begin{array}{l}0.0715^{\text {****}} \\
(0.0152)\end{array}$ & $\begin{array}{c}0.0759^{* * *} \\
(0.0132)\end{array}$ & $\begin{array}{l}0.0850^{\text {*** }} \\
(0.0132)\end{array}$ \\
\hline SAT Squared (x1000) & & $\begin{array}{l}-0.0002^{* * *} \\
(0.0001) \\
\end{array}$ & $\begin{array}{l}-0.0003^{* * *} \\
(0.0001) \\
\end{array}$ & $\begin{array}{l}-0.0004^{* * *} \\
(0.0001) \\
\end{array}$ & & $\begin{array}{r}-3.5 \mathrm{E}-05 \\
(0.0001) \\
\end{array}$ & $\begin{array}{l}-0.0002^{* * *} \\
(0.0001)\end{array}$ & $\begin{array}{l}-0.0003^{\text {*** }} \\
(0.0001)\end{array}$ \\
\hline Mean High School SAT (x100) & & & $\begin{array}{c}0.2529^{* *} \\
(0.1268)\end{array}$ & $\begin{array}{r}0.0000 \\
(0.0000)\end{array}$ & & & $\begin{array}{r}0.0421 \\
(0.1219)\end{array}$ & $\begin{array}{r}0.0000 \\
(0.0000)\end{array}$ \\
\hline Mean High School SAT Sq. (x1000) & & & $\begin{array}{l}-0.0011 \\
(0.0006)\end{array}$ & $\begin{array}{c}0.0001 \\
(0.0000)\end{array}$ & & & $\begin{array}{r}1.77 \mathrm{E}-05 \\
(0.0006)\end{array}$ & $\begin{array}{l}-0.0007^{\text {*** }} \\
(0.0000)\end{array}$ \\
\hline Feeder High School & & & $\begin{array}{l}0.0552^{* * *} \\
(0.0145)\end{array}$ & $\begin{array}{r}0.0000 \\
(0.0000)\end{array}$ & & & $\begin{array}{l}0.0811 \\
(0.0212)\end{array}$ & $\begin{array}{r}0.0000 \\
(0.0000)\end{array}$ \\
\hline Suburban & & & $\begin{array}{r}0.0041 \\
(0.0115)\end{array}$ & $\begin{array}{r}0.0075 \\
(0.0179)\end{array}$ & & & $\begin{array}{l}-0.0087 \\
(0.0102)\end{array}$ & $\begin{array}{r}0.0065 \\
(0.0175)\end{array}$ \\
\hline Town & & & $\begin{array}{c}0.0576^{* * *} \\
(0.0158)\end{array}$ & $\begin{array}{l}-0.0361 \\
(0.0221)\end{array}$ & & & $\begin{array}{r}0.0165 \\
(0.0161)\end{array}$ & $\begin{array}{l}-0.0154 \\
(0.0267)\end{array}$ \\
\hline Rural & & & $\begin{array}{c}0.0271 \\
(0.0153)\end{array}$ & $\begin{array}{l}-0.0102 \\
(0.0290)\end{array}$ & & & $\begin{array}{l}-0.0084 \\
(0.0143)\end{array}$ & $\begin{array}{r}0.0046 \\
(0.0248)\end{array}$ \\
\hline$\%$ Free Lunch & & & $\begin{array}{l}-0.0030^{* * *} \\
(0.0010)\end{array}$ & $\begin{array}{l}-0.0030 \\
(0.0012)\end{array}$ & & & $\begin{array}{l}-0.0044^{* * *} \\
(0.0010)\end{array}$ & $\begin{array}{r}0.0013 \\
(0.0010)\end{array}$ \\
\hline$\%$ Free Lunch Squared & & & $\begin{array}{r}0.0224^{*} \\
(0.0124)\end{array}$ & $\begin{array}{c}0.0337^{\text {** }} \\
(0.0136)\end{array}$ & & & $\begin{array}{c}0.0388^{* * *} \\
(0.0103)\end{array}$ & $\begin{array}{l}-0.0104 \\
(0.0107)\end{array}$ \\
\hline$\%$ Minority & & & $\begin{array}{r}0.0003 \\
(0.0010)\end{array}$ & $\begin{array}{r}0.0023 \\
(0.0029)\end{array}$ & & & $\begin{array}{l}-0.0004 \\
(0.0009)\end{array}$ & $\begin{array}{l}-0.0030 \\
(0.0034)\end{array}$ \\
\hline$\%$ Minority Squared & & & $\begin{array}{r}0.0032 \\
(0.0089)\end{array}$ & $\begin{array}{l}-0.0151 \\
(0.0240)\end{array}$ & & & $\begin{array}{r}-1.12 \mathrm{E}-05 \\
(0.0079)\end{array}$ & $\begin{array}{r}0.0270 \\
(0.0269)\end{array}$ \\
\hline Constant & $\begin{array}{c}0.8166^{* * *} \\
(0.0109)\end{array}$ & $\begin{array}{r}0.0943 \\
(0.0914)\end{array}$ & $\begin{array}{l}-1.2125^{*} \\
(0.6178)\end{array}$ & $\begin{array}{c}-0.0124 \\
(0.1174)\end{array}$ & $\begin{array}{c}0.577^{* * *} \\
(0.0134)\end{array}$ & $\begin{array}{l}-0.16722^{*} \\
(0.0786)\end{array}$ & $\begin{array}{r}-0.3324 \\
(0.6057)\end{array}$ & $\begin{array}{c}0.7016 \\
(0.1197)\end{array}$ \\
\hline Other Controls: & & & & & & & & \\
\hline Year Dummies (not shown) & Yes & Yes & Yes & Yes & Yes & Yes & Yes & Yes \\
\hline High School Fixed Effects & No & No & No & Yes & No & No & No & Yes \\
\hline Observations & 30,868 & 30,868 & 30,868 & 30,868 & 30,868 & 30,868 & 30,868 & 30,868 \\
\hline $\mathrm{R}^{2}$ & 0.06 & 0.09 & 0.11 & 0.15 & 0.11 & 0.18 & 0.20 & 0.24 \\
\hline
\end{tabular}

Notes See notes from Table 4A. 
Appendix Table A2. Difference-in-Differences Regressions: Non-minority Students (Controls Shown)

\begin{tabular}{|c|c|c|c|c|c|c|c|c|}
\hline & \multicolumn{4}{|c|}{ Panel A: Freshmen Retention } & \multicolumn{4}{|c|}{ Panel B: Graduate within 6 years } \\
\hline & Model 1 & Model 2 & Model 3 & Model 4 & Model 1 & Model 2 & Model 3 & Model 4 \\
\hline Post x Second Decile & $\begin{array}{r}0.0043 \\
(0.0064)\end{array}$ & $\begin{array}{r}0.0065 \\
(0.0063)\end{array}$ & $\begin{array}{r}0.0061 \\
(0.0062)\end{array}$ & $\begin{array}{r}0.0069 \\
(0.0062)\end{array}$ & $\begin{array}{r}-0.0104 \\
(0.0086)\end{array}$ & $\begin{array}{r}-0.0072 \\
(0.0086)\end{array}$ & $\begin{array}{r}-0.0080 \\
(0.0087)\end{array}$ & $\begin{array}{r}-0.0048 \\
(0.0088)\end{array}$ \\
\hline Post x Third and Below Deciles & $\begin{array}{c}0.0253^{* * *} \\
(0.0068)\end{array}$ & $\begin{array}{c}0.0240 \\
(0.0064)\end{array}$ & $\begin{array}{c}0.0236 \\
(0.0062)\end{array}$ & $\begin{array}{c}0.0239^{* * *} \\
(0.0062)\end{array}$ & $\begin{array}{r}0.0062 \\
(0.0093)\end{array}$ & $\begin{array}{r}0.0049 \\
(0.0087)\end{array}$ & $\begin{array}{r}0.0041 \\
(0.0083)\end{array}$ & $\begin{array}{r}0.0054 \\
(0.0082)\end{array}$ \\
\hline Second Decile & $\begin{array}{l}-0.0550 \\
(0.0046)\end{array}$ & $\begin{array}{l}-0.0369^{* * *} \\
(0.0044)\end{array}$ & $\begin{array}{l}-0.0555^{* * *} \\
(0.0042)\end{array}$ & $\begin{array}{l}-0.0582^{* * *} \\
(0.0043)\end{array}$ & $\begin{array}{l}-0.1075^{\text {*** }} \\
(0.0067)\end{array}$ & $\begin{array}{l}-0.0811 \\
(0.0066)\end{array}$ & $\begin{array}{l}-0.1154^{* * *} \\
(0.0057)\end{array}$ & $\begin{array}{l}-0.1204^{\text {*** }} \\
(0.0058)\end{array}$ \\
\hline Third and Below Deciles & $\begin{array}{l}-0.1700^{* * *} \\
(0.0094) \\
\end{array}$ & $\begin{array}{l}-0.1186^{* * *} \\
(0.0081) \\
\end{array}$ & $\begin{array}{l}-0.1543^{* * *} \\
(0.0063)\end{array}$ & $\begin{array}{l}-0.1580 \\
(0.0061)\end{array}$ & $\begin{array}{l}-0.2795^{* * *} \\
(0.0130) \\
\end{array}$ & $\begin{array}{l}-0.2058^{* * *} \\
(0.0118)\end{array}$ & $\begin{array}{l}-0.2724^{* * *} \\
(0.0075)\end{array}$ & $\begin{array}{l}-0.2781 \\
(0.0066)\end{array}$ \\
\hline Asian & & $\begin{array}{c}0.0215^{* * *} \\
(0.0037)\end{array}$ & $\begin{array}{c}0_{0.0142}{ }^{* * *} \\
(0.0043)\end{array}$ & $\begin{array}{c}0.0082^{*} \\
(0.0042)\end{array}$ & & $\begin{array}{l}-0.0121^{*} \\
(0.0065)\end{array}$ & $\begin{array}{l}-0.0271 \\
(0.0066)\end{array}$ & $\begin{array}{l}-0.0373^{* * *} \\
(0.0054)\end{array}$ \\
\hline Female & & $\begin{array}{c}0.0213^{* * *} \\
(0.0025)\end{array}$ & $\begin{array}{c}0.0135^{* * *} \\
(0.0025)\end{array}$ & $\begin{array}{c}0.01144^{* * *} \\
(0.0025)\end{array}$ & & $\begin{array}{c}0.0592^{* * *} \\
(0.0036)\end{array}$ & $\begin{array}{c}0.0447^{* * *} \\
(0.0033)\end{array}$ & $\begin{array}{l}0.0410 \\
(0.0033)\end{array}$ \\
\hline SAT $(x 100)$ & & $\begin{array}{c}0.2057^{* * *} \\
(0.0158)\end{array}$ & $\begin{array}{c}0.1816 \\
(0.0160)\end{array}$ & $\begin{array}{c}0.1654^{* * *} \\
(0.0143)\end{array}$ & & $\begin{array}{c}0.2487^{* * *} \\
(0.0143)\end{array}$ & $\begin{array}{c}0.2059^{* * *} \\
(0.0136)\end{array}$ & $\begin{array}{c}0.1638^{* * *} \\
(0.0141)\end{array}$ \\
\hline SAT Squared (x1000) & & $\begin{array}{l}-0.0008^{* * *} \\
(0.0001)\end{array}$ & $\begin{array}{l}-0.0007^{* * *} \\
(0.0001)\end{array}$ & $\begin{array}{l}-0.0006^{* * *} \\
(0.0001)\end{array}$ & & $\begin{array}{l}-0.0009^{* * *} \\
(0.0001)\end{array}$ & $\begin{array}{l}-0.0008^{* * *} \\
(0.0001)\end{array}$ & $\begin{array}{l}-0.0006 \\
(0.0001)\end{array}$ \\
\hline Mean High School SAT (x100) & & & $\begin{array}{c}0^{0.1681} \\
(0.0525)^{* * *}\end{array}$ & $\begin{array}{r}0.0000 \\
(0.0000)\end{array}$ & & & $\begin{array}{r}0.1424 \\
(0.0944)\end{array}$ & $\begin{array}{r}0.0000 \\
(0.0000)\end{array}$ \\
\hline Mean High School SAT Sq. (x1000) & & & $\begin{array}{l}-0.0006^{* *} \\
(0.0003)\end{array}$ & $\begin{array}{c}0.0000 \\
(0.0000)\end{array}$ & & & $\begin{array}{l}-0.0004 \\
(0.0005)\end{array}$ & ${ }^{0.0001}{ }^{* * * *}$ \\
\hline Feeder High School & & & $\begin{array}{c}0.0311 \\
(0.0078)\end{array}$ & $\begin{array}{r}0.0000 \\
(0.0000)\end{array}$ & & & $\begin{array}{c}0.0612 \\
(0.0130)\end{array}$ & $\begin{array}{r}0.0000 \\
(0.0000)\end{array}$ \\
\hline Suburban & & & $\begin{array}{r}0.0004 \\
(0.0063)\end{array}$ & $\begin{array}{r}0.0010 \\
(0.0055)\end{array}$ & & & $\begin{array}{r}0.0010 \\
(0.0101)\end{array}$ & $\begin{array}{r}-0.0038 \\
(0.0103)\end{array}$ \\
\hline Town & & & $\begin{array}{c}-0.0002 \\
(0.0066)\end{array}$ & $\begin{array}{r}-0.0096 \\
(0.0106)\end{array}$ & & & $\begin{array}{l}-0.0051 \\
(0.0092)\end{array}$ & $\begin{array}{r}-0.0109 \\
(0.0123)\end{array}$ \\
\hline Rural & & & $\begin{array}{r}-0.0008 \\
(0.0079)\end{array}$ & $\begin{array}{c}0.0159 \\
(0.0091)\end{array}$ & & & $\begin{array}{l}-0.0028 \\
(0.0112)\end{array}$ & $\begin{array}{r}0.0098 \\
(0.0125)\end{array}$ \\
\hline$\%$ Free Lunch & & & $\begin{array}{l}-0.0005 \\
(0.0006)\end{array}$ & $\begin{array}{r}0.0001 \\
(0.0007)\end{array}$ & & & $\begin{array}{l}-0.0021 \\
(0.0009)\end{array}$ & $\begin{array}{r}-0.0005 \\
(0.0010)\end{array}$ \\
\hline$\%$ Free Lunch Squared & & & $\begin{array}{c}-0.0027 \\
(0.0094)\end{array}$ & $\begin{array}{r}0.0093 \\
(0.0119)\end{array}$ & & & $\begin{array}{r}0.0092 \\
(0.0150)\end{array}$ & $\begin{array}{r}0.0146 \\
(0.0165)\end{array}$ \\
\hline$\%$ Minority & & & $\begin{array}{l}9.2 \mathrm{E}-06 \\
(0.0005)\end{array}$ & $\begin{array}{r}0.0012 \\
(0.0010)\end{array}$ & & & $\begin{array}{r}0.0004 \\
(0.0008)\end{array}$ & $\begin{array}{c}-0.0001 \\
(0.0015)\end{array}$ \\
\hline$\%$ Minority Squared & & & $\begin{array}{l}-0.0001 \\
(0.0052)\end{array}$ & $\begin{array}{l}-0.0145 \\
(0.0096)\end{array}$ & & & $\begin{array}{l}-0.0033 \\
(0.0087)\end{array}$ & $\begin{array}{l}-0.0134 \\
(0.0137)\end{array}$ \\
\hline Constant & $\begin{array}{c}0.9364^{* * *} \\
(0.0037)\end{array}$ & $\begin{array}{l}-0.4446^{* * *} \\
(0.0969)\end{array}$ & $\begin{array}{l}-1.2867^{* * *} \\
(0.2887)\end{array}$ & $\begin{array}{l}-0.1874^{* *} \\
(0.0903)\end{array}$ & $\begin{array}{c}0.8129^{* * *} \\
(0.0060)\end{array}$ & $\begin{array}{l}-0.9021 \\
(0.0892)\end{array}$ & $\begin{array}{l}-1.5455^{\text {*** }} \\
(0.4905)\end{array}$ & $\begin{array}{l}-0.2736 \\
(0.0932)\end{array}$ \\
\hline Other Controls: & & & & & & & & \\
\hline Year Dummies (not shown) & Yes & Yes & Yes & Yes & Yes & Yes & Yes & Yes \\
\hline High School Fixed Effects & No & No & No & Yes & No & No & No & Yes \\
\hline Observations & 89,584 & 89,584 & 89,584 & 89,584 & 89,584 & 89,584 & 89,584 & 89,584 \\
\hline $\mathrm{R}^{2}$ & 0.04 & 0.07 & 0.08 & 0.11 & 0.07 & 0.10 & 0.12 & 0.15 \\
\hline
\end{tabular}

Notes See notes from Table 4B. 